\title{
Global-scale analysis of river flow alterations due to water withdrawals and reservoirs
}

\author{
P. Döll, K. Fiedler, and J. Zhang \\ Institute of Physical Geography, Goethe University Frankfurt, Frankfurt am Main, Germany \\ Received: 17 June 2009 - Published in Hydrol. Earth Syst. Sci. Discuss.: 3 July 2009 \\ Revised: 24 November 2009 - Accepted: 6 December 2009 - Published: 22 December 2009
}

\begin{abstract}
Global-scale information on natural river flows and anthropogenic river flow alterations is required to identify areas where aqueous ecosystems are expected to be strongly degraded. Such information can support the identification of environmental flow guidelines and a sustainable water management that balances the water demands of humans and ecosystems. This study presents the first global assessment of the anthropogenic alteration of river flow regimes, in particular of flow variability, by water withdrawals and dams/reservoirs. Six ecologically relevant flow indicators were quantified using an improved version of the global water model WaterGAP. WaterGAP simulated, with a spatial resolution of 0.5 degree, river discharge as affected by human water withdrawals and dams around the year 2000, as well as naturalized discharge without this type of human interference. Compared to naturalized conditions, long-term average global discharge into oceans and internal sinks has decreased by $2.7 \%$ due to water withdrawals, and by $0.8 \%$ due to dams. Mainly due to irrigation, long-term average river discharge and statistical low flow $Q_{90}$ (monthly river discharge that is exceeded in 9 out of 10 months) have decreased by more than $10 \%$ on one sixth and one quarter of the global land area (excluding Antarctica and Greenland), respectively. $Q_{90}$ has increased significantly on only $5 \%$ of the land area, downstream of reservoirs. Due to both water withdrawals and reservoirs, seasonal flow amplitude has decreased significantly on one sixth of the land area, while interannual variability has increased on one quarter of the land area mainly due to irrigation. It has decreased on only $8 \%$ of the land area, in areas downstream of reservoirs where consumptive water use is low. The impact of reservoirs is likely underestimated by our study as small reservoirs are not taken into account. Areas most affected by anthropogenic river
\end{abstract}

Correspondence to: P. Döll

(p.doell@em.uni-frankfurt.de) flow alterations are the Western and Central USA, Mexico, the western coast of South America, the Mediterranean rim, Southern Africa, the semi-arid and arid countries of the Near East and Western Asia, Pakistan and India, Northern China and the Australian Murray-Darling Basin, as well as some Arctic rivers. Due to a large number of uncertainties related e.g. to the estimation of water use and reservoir operation rules, the analysis is expected to provide only first estimates of river flow alterations that should be refined in the future.

\section{Introduction}

Freshwater ecosystems, which include rivers, wetlands and lakes as well as their floodplains, have been deteriorating faster than other ecosystems. According to the Millennium Ecosystem Assessment (2005), populations of freshwater species (included in the Living Planet Index) declined, between 1970 and 2000 , on average by $50 \%$, compared to $30 \%$ for marine and also for terrestrial species. Approximately $20 \%$ of the world's 10000 described freshwater fish species have been listed as threatened, endangered, or extinct in the last few decades. Over one third (37\%) of the freshwaterdependent mammal species assessed for the IUCN Red List were globally threatened, including manatees, river dolphins and porpoises (Millenium Ecosystem Assessment, 2005). Besides, about one half of the 200 species of freshwater turtles were classified as globally threatened in the IUCN Red List. Threats to global freshwater biodiversity can be grouped under five categories: overexploitation, invasion by exotic species, water pollution, destruction or degradation of habitat (e.g. related to changes in fluvial morphology), and alteration of flow regimes (Dudgeon et al., 2006). While the first two relate to the biotic component of freshwater ecosystems, the latter affect the abiotic component.

Published by Copernicus Publications on behalf of the European Geosciences Union. 
Monitoring of freshwater species is required to characterize the degree to which humans have affected aquatic ecosystems. The knowledge of the status and trend of freshwater species, however, is still very poor, in particular in developing countries, and it is not likely to significantly improve in the near future (Revenga et al., 2005). Therefore, assessment and monitoring of the physical conditions of the freshwater habitat is an option, firstly because it provides a more integrated characterization of ecosystem change, and secondly because physical data may be available at more locations than species data (Revenga et al., 2005). Humans have significantly influenced most rivers of the world with respect to the physical habitat conditions water quality, fluvial morphology, and flow regimes (Dudgeon et al., 2006). Changes in water quality are predominantly due to human and animal excretions as well as agricultural and industrial emissions, while fluvial morphology has been modified mainly to improve navigation and flood protection. River flow regimes have been altered by water withdrawals as well as by reservoir construction and management. These alterations do not only affect river ecosystems themselves but also associated ecosystems like riparian wetlands and floodplains.

Many studies have shown that flow regimes play a major role in determining the biotic composition, structure, function and diversity within river ecosystems (Richter et al., 1996; Arthington and Pusey, 1993). The importance of flow variability for river ecosystems has been well documented (e.g. Poff and Ward, 1989; Poff et al., 1997; Richter et al., 1996, 1997; Puckridge et al., 1998; Clausen and Biggs, 2000; World Commission on Dams, 2000). Researchers now generally agree on the "natural flow paradigm", stating that the full range of natural intra- and interannual variability of hydrological regimes is critical in sustaining native biodiversity and integrity of aquatic ecosystems (Richter et al., 1997; Poff et al., 1997). Thus, environmental flow guidelines must take into account flow variability as expressed by a number of indicators, not just prescribe minimum flows. The natural flow paradigm also suggests that approaches for defining environmental water requirements only as fraction of longterm average flows, like the Smakhtin et al. (2004) approach, are overly simplistic and inappropriate for protecting ecosystems.

A comparison of the natural flow regime of a river with the flow regime that is affected by human intervention provides an indication for the degree of human alteration or degradation of the freshwater ecosystem. Such a comparison requires the identification of appropriate hydrological indicators that are relevant for the well-being of the biotic components of the freshwater ecosystem (Black et al., 2005). The Indicators of Hydrologic Alteration (IHA) approach of Richter et al. (1996) has been widely adopted because of its comprehensive ability to characterize ecologically relevant hydrological changes. In this method, two sets of flow time series representing natural and altered conditions at the same site are compared using 32 indicators of flow magnitude, fre- quency, duration, timing and rate of change. Large differences between natural and actual, i.e. anthropogenically altered, regimes are likely to indicate that the biotic components of the aquatic ecosystem have been altered too, and that biodiversity has been decreased due to human impacts.

Both reservoirs and water withdrawals result in increased evapotranspiration and thus decreased annual river flow values, and they affect the seasonality of river flow. Reservoirs lead to decreased seasonal flow amplitudes, while the impact of water withdrawals depends on their seasonality. For the Krishna River in India, for example, Bouwer et al. (2006) showed that reservoir construction and pertaining irrigation after 1960 had lead to decreased annual runoff, decreased monsoon season flows and somewhat increased postmonsoon season flows. Studies on both the impact of reservoirs and water withdrawals on flow regimes and the impact of altered flow regimes on the biotic ecosystem component mainly concern North American or Australian rivers. For the Murrumbidgee River in Australia, for example, Kingsford and Thomas (2004) described a river flow reduction to about one third of the natural median flow, and the resulting degradation of the major wetland caused by damming and subsequent water withdrawals. This led to a $21 \%$ reduction of the number of water bird species and a $90 \%$ reduction of the total number of water birds between 1983 and 2001. For the Brazos River basin in the USA, with large and increasing water withdrawals and 39 reservoirs, Vogl and Lopes (2009) compared naturalized and anthropogenically impacted river flow regimes. They identified decreases in the frequency of high flow events (in spring and winter) and increased summer low flows. These changes likely caused the observed increase of habitat generalist fish species, a decrease of native riverine fishes and an overall homogenization of species assemblages. Analyzing the temporal development of 186 intermediate-sized rivers affected by dams in the continental USA, Poff et al. (2007) found that flow regimes have become more homogeneous due to modification of ecologically critical high and low flows. Such a homogenization, which favors the spread of cosmopolitan, nonindigenous species, was not identified for 317 undammed reference rivers.

At the global scale, what is known about the drivers of river flow regime alteration, i.e. water use and dams? Total global water withdrawals are estimated to be $4000 \mathrm{~km}^{3} / \mathrm{yr}$, approximately one tenth of the renewable water resources (Döll, 2009), but ratios exceed 0.4 in many river basins which are then called "water-stressed". These cover about one quarter of the global land area outside the ice caps and are the home of more than 2 billion people (Alcamo et al., 2003a). Consumptive water use (i.e. the fraction of the withdrawn water that evapotranspirates during use and therefore does not return to the river) leads to river discharge reduction and is therefore the relevant quantity for determining human river flow alterations. It amounts to $1300-1400 \mathrm{~km}^{3} / \mathrm{yr}$, of which more than $90 \%$ are caused by irrigation (Döll, 2009). Therefore, river flow reductions due to human water use are high 
in semi-arid and arid areas with significant irrigation.

Avakyan and Iakovleva (1998) estimated that there were around 60000 reservoirs world-wide, but gave no lower size limit. They estimated that their total capacity exceeds $6500 \mathrm{~km}^{3}$ and that their water surface equals $400000 \mathrm{~km}^{2}$. According to ICOLD (1998), there are more than 45000 large dams (with a dam height of more than $15 \mathrm{~m}$, or of more than $5 \mathrm{~m}$ if the reservoir volume is above 3 million $\mathrm{m}^{3}$ ), but part of these dams are run-of-river dams without significant water storage and thus with a small effect on the flow regime. Chao et al. (2008), mainly based on ICOLD data, studied the development of total global water storage in reservoirs between 1900 and 2007, taking into account almost 30000 reservoirs with, after 2000, a storage capacity of approx. $8300 \mathrm{~km}^{3}$. Unfortunately, neither ICOLD nor Chao et al. (2008) include the geographical coordinates of the dams and reservoirs. Nilsson et al. (2005) found that 172 out of 292 large river systems (i.e. 60\%) are affected by dams. While Europe has almost no unfragmented large river systems, there are many unfragmented systems in North and Central America (outside the USA). The investigated 292 river systems account for $60 \%$ of the world's river discharge. Analyzing around 600 of the largest reservoirs world-wide, Vörösmarty et al. (1997) found that the mean age of river water has likely tripled to well over one month, which shows the increase of transport time of river water due to reservoirs. Poff et al. (2007) stated that extensive construction of dams has greatly dampened seasonal and interannual river discharge variability, with negative impacts on global biodiversity in river and riparian ecosystems as biodiversity is generated and maintained by geographic variation.

The objective of this study was to analyze the impact of water withdrawals and dams (i.e. reservoirs or regulated lakes) on monthly and annual river flow regimes world-wide, considering ecologically-relevant hydrologic indicators. We wanted to represent the alteration of natural conditions that had occurred by around the year 2000 due to withdrawals and dams only, under climatic conditions that had not yet been appreciably altered by climate change (i.e. before 1990). We used the global hydrology and water use model WaterGAP (Alcamo et al., 2003b) which takes into account the impact of reservoirs and water withdrawals on river discharge. For this study, we applied the most recent model version $2.1 \mathrm{~g}$. It differs from the previous version $2.1 \mathrm{f}$ as presented in Hunger and Döll (2008) with respect to the implementation of the reservoir algorithm of Hanasaki et al. (2006), and of the new GRanD reservoir data set (Lehner et al., 2008; Lehner et al., 2009). With this version, the impact of more than 6500 reservoirs and regulated lakes could be analyzed. The model was used to generate time series of anthropogenically altered river discharge, and of naturalized discharge that would occur if there were no dams or water withdrawals. This allowed the quantification of anthropogenic river flow alterations.
In Sect. 2, the methods to compute anthropogenically altered and naturalized river flows, the selected indicators of river flow alteration and a simple approach for relating changes of annual flows to changes of the number of fish species are described. In Sects. 3 and 4, results are presented and discussed. In the last section, we summarize the study results and draw conclusions.

\section{Methods}

\subsection{Computation of natural and anthropogenically altered river flows with WaterGAP}

The global water resources and use model WaterGAP consists and the WaterGAP Global Hydrology Model WGHM and of a number of sectoral water use models (Alcamo et al., $2003 \mathrm{~b}$ ). With a spatial resolution of $0.5^{\circ}$ by $0.5^{\circ}(55 \mathrm{~km}$ by $55 \mathrm{~km}$ at the equator), it covers all land areas of the globe excluding Antarctica. Water use, i.e. water withdrawals and consumptive water use, is estimated separately for the sectors irrigation, livestock, households and industry. With a daily time step, WGHM computes water storage and water flows, including total runoff generation, groundwater recharge and river discharge, taking into account the impact of human water use on river discharge and surface water storage (Döll et al., 2003; Döll and Fiedler, 2008). WGHM is tuned in a basin-specific manner against long-term average discharges at 1235 gauging stations (Hunger and Döll, 2008).

For each grid cell of WGHM, a vertical water balance is computed, and the resulting runoff is routed laterally within the cell through a groundwater store and various types of surface water stores (lakes, reservoirs, wetlands, and rivers). The effect of surface water storage on water balance and flow dynamics is modeled by first routing the runoff generated within the grid cell through a so-called "local" lake/reservoir storage and a "local" wetland storage compartment. The resulting discharge volume is added to the discharge from the upstream grid cell and routed through a so-called "global" lake and/or reservoir compartment and a "global" wetland storage compartment, and finally through the river storage compartment. If there are a number of lakes (or reservoirs or wetlands) within a grid cell, they are lumped into one. "Local" lakes and reservoirs are lumped together into one "local" lake, too, while "global" lakes and "global" reservoirs are treated separately within the cell. The water balance of "global" lakes and reservoirs, which can cover more than one grid cell, is computed in the grid cell where the outflow of the lake or reservoir is located. The difference between precipitation and potential evapotranspiration is added to the water balance of lakes, reservoirs and wetlands, thus taking into account the effect of the surface water balance on cell runoff.

Global lakes and reservoirs are defined based on their size, exceeding a surface area of $100 \mathrm{~km}^{2}$ or a maximum storage capacity of $0.5 \mathrm{~km}^{3}$. In former versions of WGHM including 
WGHM $2.1 \mathrm{f}$ (Hunger and Döll, 2008; Döll and Fiedler, 2008), reservoirs were modeled like natural lakes, where outflow is computed as a nonlinear function of water storage. Evapotranspiration from lakes (and wetlands) is reduced at low storage values, and outflow is stopped (Hunger and Döll, 2008). In WGHM $2.1 \mathrm{~g}$ used here, reservoir management is simulated following the approach of Hanasaki et al. (2006) which is explained in Sect. 2.1.3 below. In addition, the database of lakes, reservoirs and wetlands that was used in version $2.1 \mathrm{f}$ (Lehner and Döll, 2004), has been enhanced by inclusion of a larger number of man-made reservoirs (comp. Sect. 2.1.3).

Important WGHM inputs are time series of monthly values of climate variables as well as information on soil and land cover. Monthly climate data are downscaled to daily data, in the case of precipitation using the number of wet days per month. Monthly climate data, except precipitation, are provided by the CRU TS 2.1 data set (Mitchell and Jones, 2005). As precipitation input, $0.5^{\circ}$ gridded monthly time series of the GPCC Full Data Product Version 3 (Fuchs et al., 2008) were used, together with the number of wet days from the CRU TS 2.1 data set.

\subsubsection{Specification of model runs}

Five time series (ANT, NAT, RES, USE, ANT LAKE) of gridded monthly river discharge from 1961-1990 were computed by WHGM, which were then used to quantify the indicators of river flow regime alteration described in Sect. 2.2. In our analysis, ANT conditions refer to the flow regime as impacted by human water withdrawals as well as by reservoirs and regulated lakes. This simulation is the standard WGHM simulation for which tuning was performed. During tuning, observed long-term average discharge at the basin outlet was compared to modeled long-term average discharge during the observation time periods. Modeled discharge took into account the time-varying consumptive use during the tuning period, but it was assumed that the reservoirs existed during the whole tuning period. NAT refers to the naturalized regime as computed by a run with the tuned model in which there are no water withdrawals and in which all reservoirs are removed while regulated lakes are not treated like reservoirs but like natural lakes. Under RES conditions, there are no water withdrawals but reservoirs and regulated lakes exist. Under USE conditions, the impact of water withdrawals on river discharge is simulated but not the impact of reservoirs and lake regulation. To show the effect of the newly implemented reservoir algorithm, the model run ANT LAKE was designed in which all reservoirs were treated like natural lakes, like in previous model versions. In the following two sections, the methods to simulate the impact of human water withdrawals and of dams/reservoirs on river discharge are explained in detail.

\subsubsection{Reduction of river flow due to human water withdrawals}

For the computation of indicators of river flow alteration due to human water withdrawals, domestic, industrial and livestock water use in 2002 as computed by the respective WaterGAP water use models was taken into account. Irrigation water use was computed according to Döll and Siebert (2002) using, as input, 1) version 4.0.1 of the Global Map of Irrigated Areas GMIA (Siebert et al., 2005), (2) estimates of actually irrigated area per country in 2002 and (3) the climate data time series 1961-1990, to take into account the effect of climate variability on irrigation water use. While domestic, industrial and livestock water uses are assumed to be constant within each year, irrigation water use varies from month to month. In WGHM, the effect of human water withdrawals is simulated by subtracting total consumptive water use from river discharge, or from the water stored in lakes and reservoirs, if there are any in the grid cell and there is not enough water available from the river itself. Consumptive use of a cell is supplied from the cell itself, or from the neighboring cell with the highest long-term average river discharge if not enough water is available in the cell itself.

Consumptive water use is particularly high in India, Pakistan, parts of China and the USA and in the Mediterranean region, mainly due to the large irrigation areas there (Fig. 1a). Global consumptive water use has more than doubled between 1951 and 2002, reaching about $1300-1400 \mathrm{~km}^{3} / \mathrm{yr}$ around 2000 (Fig. 1b). Irrigation accounts for more than $90 \%$ of the global consumptive water use. In dry years, irrigation water requirements are particularly high, which results in a stronger anthropogenic reduction of the already naturally low river discharge.

Due to various reasons, it is not always possible in WHGM to subtract the total daily consumptive use from rivers, lakes or reservoirs, due to a lack of water. One reason is the likely overestimation of irrigation water use by the WaterGAP irrigation water use model (Döll and Siebert, 2002), as in dry years, farmers might not have enough water to irrigate all fields with the optimal amount. Another reason may be long-distance water transfers, which are not represented in WGHM. In addition, non-renewable groundwater is withdrawn in reality, e.g. in the USA, Libya, Saudi-Arabia or China (Custodio, 2001; Foster and Loucks, 2006). Currently, we cannot model groundwater withdrawals explicitly because it is not known (globally) which part of the water use comes from groundwater or surface water. Thus, in WGHM, we attempt to withdraw all water from surface water sources. If on any day there is not enough water available in surface waters to satisfy the consumptive use, the model will take out this consumptive water use later in the year or in the next year. This approximates withdrawals from renewable groundwater resources, as, in reality, groundwater can be withdrawn even in periods with low river flows. The delayed satisfaction of water requirement leads to a stronger 

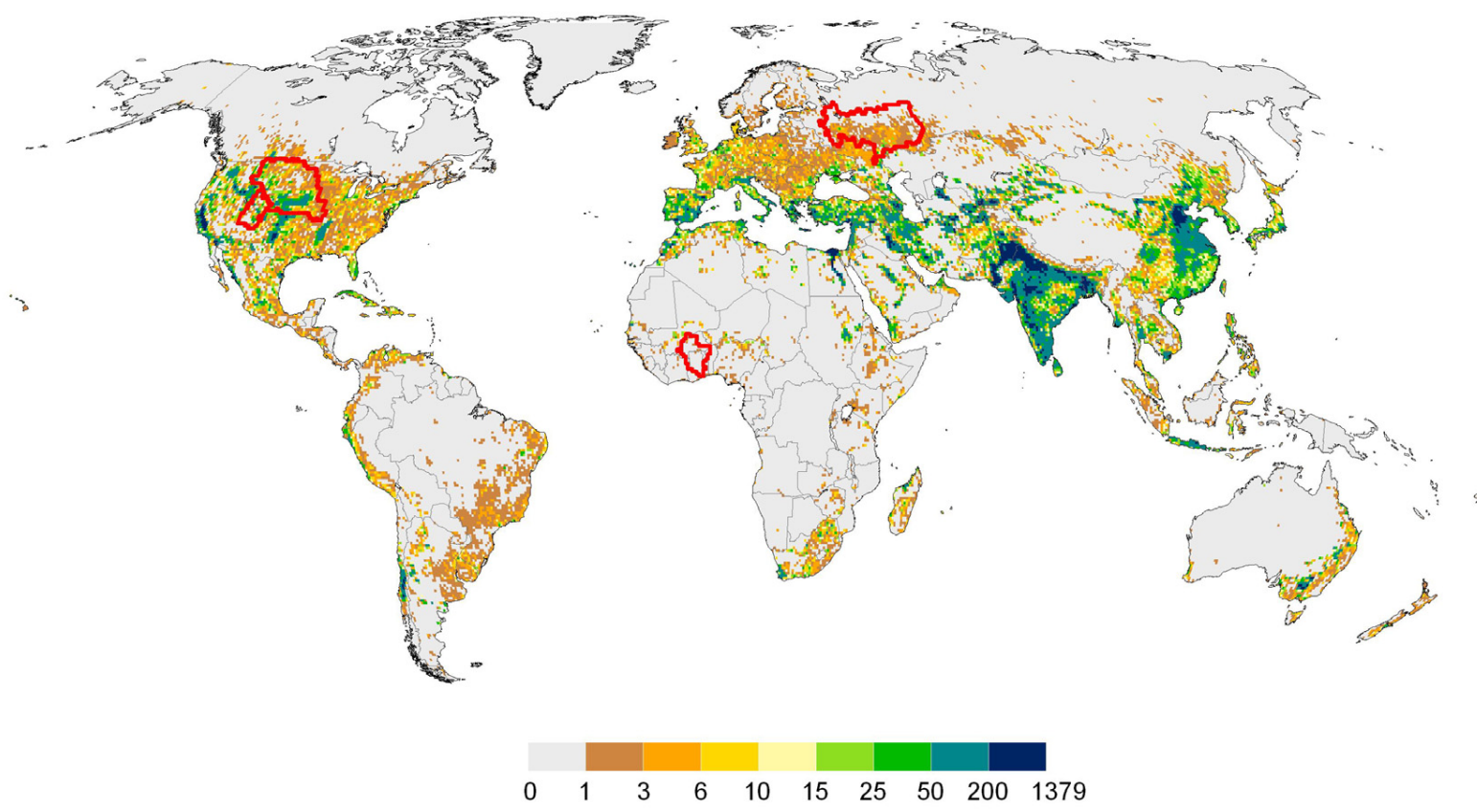

a)

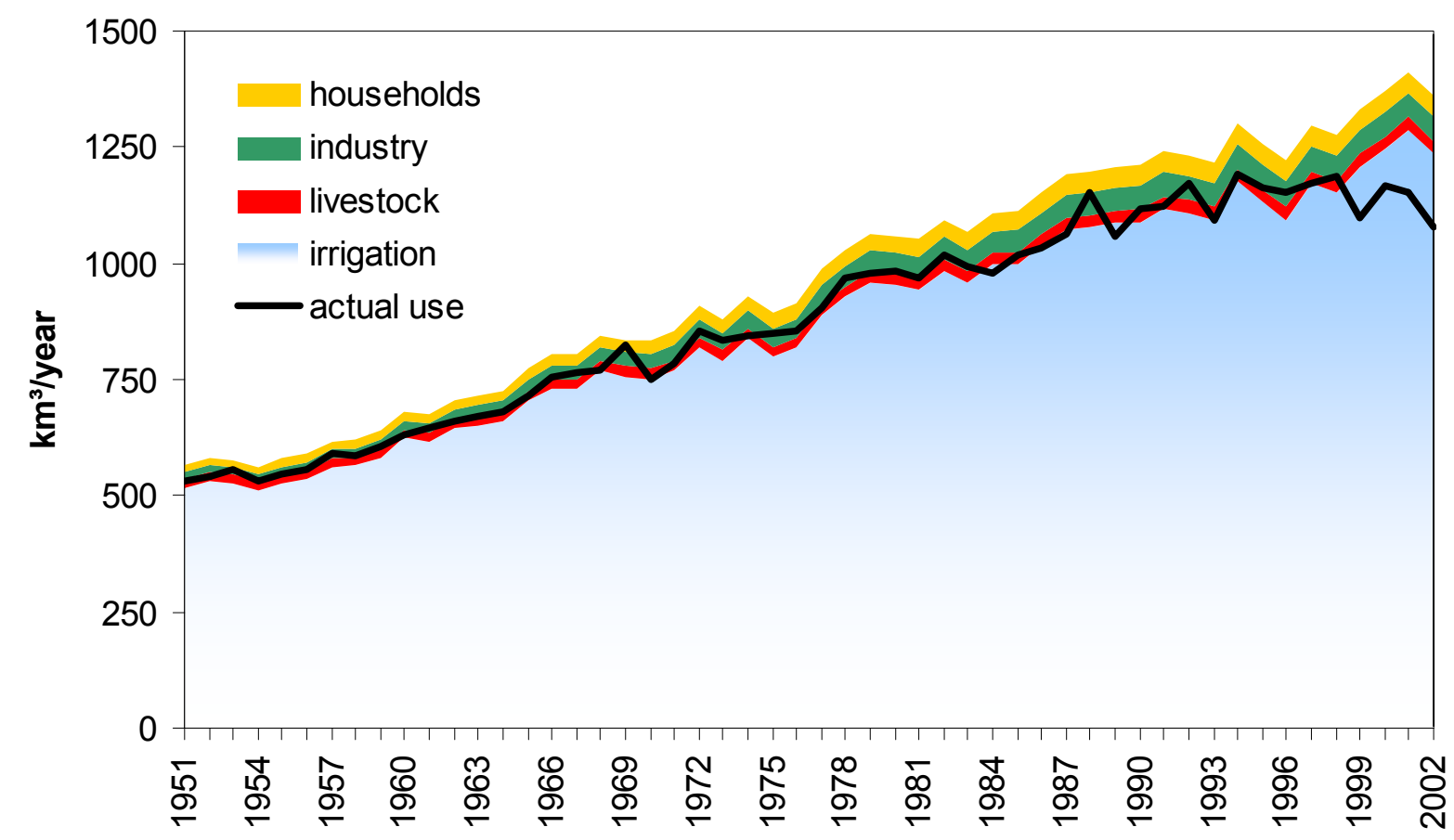

b)

Fig. 1. Consumptive water use in 2002, in mm/yr (a), and time series 1951-2002 of global consumptive water use, using climate and irrigated areas of particular year (b), as simulated by the WaterGAP water use models. In Fig. 1a, the location of the four basins discussed in Sect. 4 is shown. In Fig. 1b, actual use refers to the part of the computed consumptive use that can actually be taken out of water storage in the WaterGAP Global Hydrology Model WGHM. 


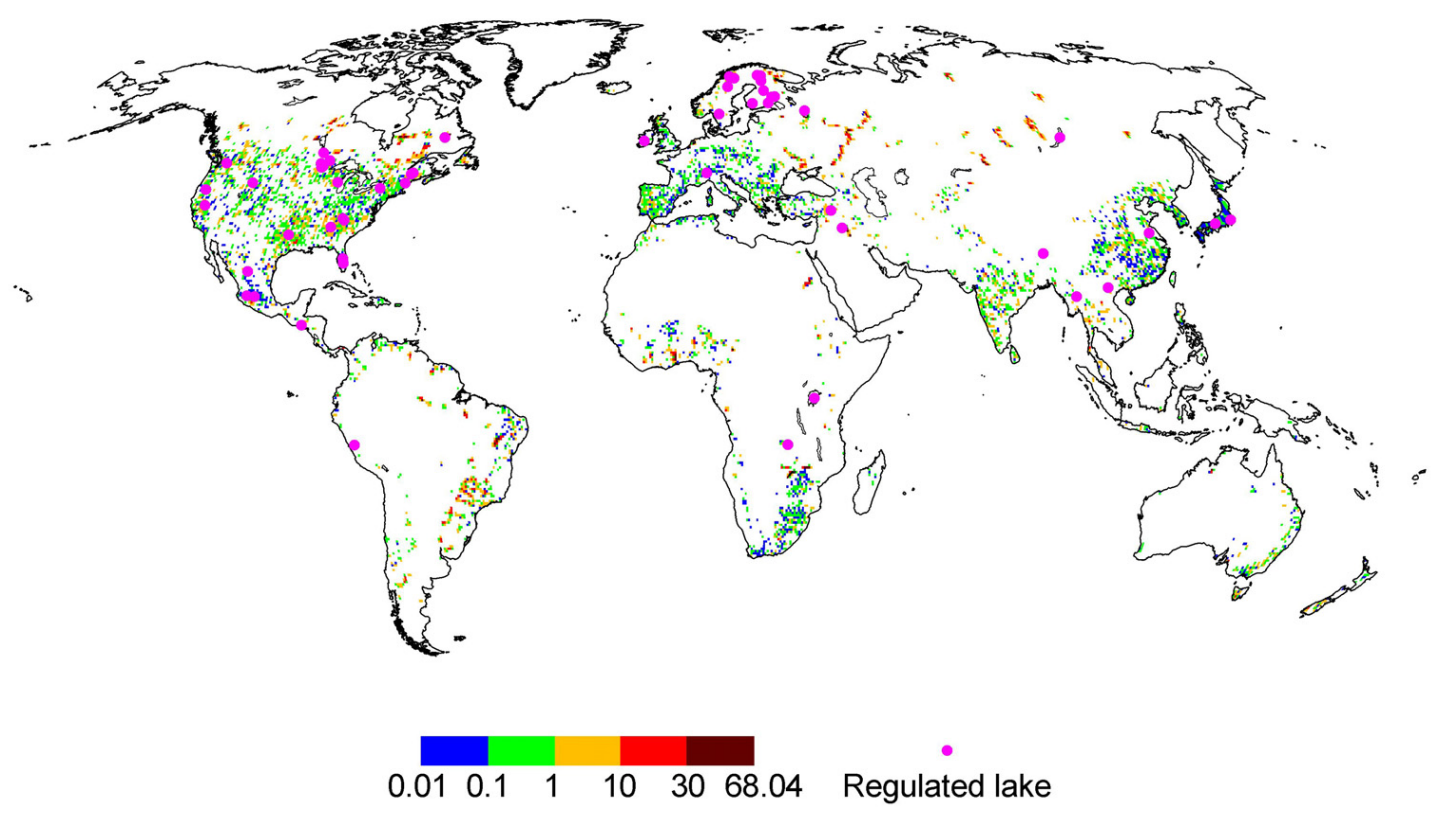

Fig. 2. Reservoir area in percent of $0.5^{\circ}$ grid cell area, and location of regulated lakes.

discharge reduction in the river (as compared to simulations where delayed satisfaction is not allowed), which is more realistic if groundwater that is connected to surface waters is actually withdrawn. Also, groundwater withdrawals in a certain month lead to delayed response of baseflow to the river, which is also somehow reflected by the delayed satisfaction approach. Nevertheless, actual temporal variations of the effect of water withdrawals on surface water flows are only approximated very roughly. The "actual use" line in Fig. 1b shows that the fraction of water demand that can be fulfilled from renewable water resources has been decreasing in recent decades, in line with the increasing demand. The difference between "actual use" and total demand, which reaches a maximum of about $20 \%$ of the demand, is expected to be caused mainly by overestimation of actual water withdrawals due to deficit (sub-optimal) irrigation, and by withdrawal of non-renewable groundwater. Whether the imperfect consideration of water use leads to an over- or underestimation of the reduction of river flows due to human water use is not known, both at the global and the grid scales.

\subsubsection{Modification of river flows due to reservoir operation}

For this study, we needed to distinguish between man-made reservoirs and regulated lakes, i.e. natural lakes whose outflows are regulated by a dam. This was required because under naturalized conditions (NAT), reservoirs do not exist at all, while regulated lakes are treated as natural lakes. Under anthropogenically altered conditions, reservoirs and regulated lakes are modeled by the same algorithm.
The new reservoirs and regulated lakes data set includes 6553 reservoirs and 52 regulated lakes (Table 1 and Fig. 2). It was derived by adding additional reservoirs from a preliminary (July 2008) version of the GRanD database (Lehner et al., 2008; Lehner et al., 2009) to the 886 reservoirs included in WGHM $2.1 \mathrm{f}$. For WHGM $2.1 \mathrm{f}$, the Global Lakes and Wetlands Database of Lehner and Döll (2004) had already been augmented by 64 reservoirs. The development of the GRanD data set aimed at including, as polygons, all reservoirs world-wide with a storage capacity of more than $0.1 \mathrm{~km}^{3}$. While for Europe and the USA, this goal was probably reached, it is believed that the dataset is incomplete particularly in China, India and South America. GRanD does not distinguish between regulated lakes and reservoirs. Therefore, all "global" reservoirs (with an area of more than $100 \mathrm{~km}^{2}$ or a maximum storage volume of at least $0.5 \mathrm{~km}^{3}$ ) were checked to decide whether they are actually regulated lakes. This resulted in the identification of 52 "global" regulated lakes, in addition to 1022 "global" reservoirs. "Global" reservoirs and lakes are assumed to be fed by river discharge from the upstream cell, while smaller reservoirs are assumed to be "local", i.e. they are only fed by the runoff generated within the grid cell.

The majority of reservoirs are in North America and Asia (Fig. 2). The surface area of the reservoirs and regulated lakes is $291000 \mathrm{~km}^{2}$ and $124000 \mathrm{~km}^{2}$, respectively, as compared to a total of $254000 \mathrm{~km}^{2}$ in version $2.1 \mathrm{f}$. Maximum storage capacity of reservoirs and regulated lakes is $5930 \mathrm{~km}^{3}$ and $405 \mathrm{~km}^{3}$, respectively, vs. $4642 \mathrm{~km}^{3}$ before (Table 1). Please note that many of the new reservoirs were formerly included as lakes. The newest dams taken into 
Table 1. Reservoirs and regulated lakes taken into account in this study. Data based on a preliminary version of the GRanD data base, (Lehner et al., 2008, 2009).

\begin{tabular}{lrrrrrrrrr}
\hline & \multicolumn{3}{c}{ number } & \multicolumn{3}{c}{ surface area $\left[\mathrm{km}^{2}\right]$} & \multicolumn{2}{c}{ storage capacity ${ }^{\mathrm{a}}\left[\mathrm{km}^{3}\right]$} \\
& old $^{\mathrm{b}}$ & $\begin{array}{c}\text { reser- } \\
\text { voirs }\end{array}$ & $\begin{array}{c}\text { regul. } \\
\text { lakes }\end{array}$ & old $^{\mathrm{b}}$ & $\begin{array}{r}\text { reser- } \\
\text { voirs }\end{array}$ & $\begin{array}{r}\text { regul. } \\
\text { lakes }\end{array}$ & old $^{\mathrm{b}}$ & $\begin{array}{r}\text { reser- } \\
\text { voirs }\end{array}$ & $\begin{array}{r}\text { regul. } \\
\text { lakes }\end{array}$ \\
\hline Africa & 170 & 678 & 2 & 38899 & 40238 & 67380 & 1302.7 & 1807.3 & 90.5 \\
Asia & 171 & 1952 & 9 & 47914 & 61607 & 35939 & 804.7 & 877.3 & 206.5 \\
Europe $^{\mathrm{c}}$ & 150 & 1097 & 15 & 45525 & 42340 & 10313 & 419.0 & 541.3 & 53.4 \\
Oceania $^{\mathrm{d}}$ & 30 & 238 & 0 & 5303 & 7899 & 0 & 80.0 & 110.0 & 0 \\
N. America & 269 & 2302 & 25 & 69051 & 87663 & 9735 & 1250.9 & 1590.7 & 54.5 \\
S. America & 96 & 288 & 1 & 47610 & 51169 & 147 & 785.7 & 1002.8 & 0.6 \\
Global & 886 & 6553 & 52 & 254301 & 290916 & 123513 & 4642.0 & 5929.5 & 405.4 \\
\hline
\end{tabular}

a Only 672 reservoirs in "old" version and 6512 reservoirs in the current version of the reservoirs and regulated lakes data set were used to calculate the storage capacity because of lack of storage capacity data. Storage capacity of regulated lakes includes all 52 regulated lakes.

$\mathrm{b}$ taken into account in previous WGHM model version $2.1 \mathrm{f}$ (Hunger and Döll, 2008).

${ }^{\mathrm{c}}$ Eurasia is subdivided into Europe and Asia along the Ural; Turkey is assigned to Asia.

$\mathrm{d}$ including Australia, New Zealand, the Pacific island and Papua New Guinea.

account in this study were finished in 2006 but the data set certainly does not cover all reservoirs that existed in 2006. The Three Gorges Dam on the Yangtze River in China is included but not the dams at the Narmada River in India.

The reservoir operation algorithm of Hanasaki et al. (2006) was implemented in WGHM for 1074 global reservoirs and regulated lakes, while flow dynamics of local reservoirs were modeled like those of natural lakes. One reason for the latter is that the required lumping of all local reservoirs within a grid cell into one local reservoir per cell necessarily leads to a "blurring" of the specific reservoir characteristics, such that for local reservoirs, the reservoir algorithm is not expected to simulate water storage and fluxes better than the lake algorithm.

Hanasaki et al. (2006) developed two different algorithms, one for reservoirs with irrigation as their main purpose, and another for all other reservoir types. In both cases, annual release is a function of the long-term average annual reservoir inflow and relative water storage at the beginning of the operational year. The operational year is computed based on the seasonal flow dynamics since no independent data are available. Different from Hanasaki et al. (2006), in WGHM the annual release is a function of the long-term average value of reservoirs inflows plus the difference between precipitation and evaporation over the reservoir, as the long-term average annual outflow of a reservoir depends not only on the inflows but also on the reservoir water balance, in particular in case of large reservoirs (and regulated lakes). In the case of non-irrigation reservoirs, monthly outflows are assumed to be constant throughout the operational year. The monthly fluctuation of releases of irrigation reservoirs depends on monthly downstream consumptive water use, taking into account water use in the next five downstream cells, or down to the next reservoir or the river mouth. This is different from Hanasaki et al. (2006), who took into account water use in a maximum of $101^{\circ}$ grid cells downstream, and preferred water withdrawals to consumptive use. With the shorter range in the WGHM version, we mostly avoid that there is more than one reservoir that could provide water for a certain cell. Overflow occurs if reservoir storage capacity would be exceeded.

In WGHM, reservoir storage is not allowed to fall below $10 \%$ of storage capacity, neither due to reservoir releases nor due to consumptive water use. Reservoir evapotranspiration is reduced with decreasing reservoir storage, by multiplying potential evaporation with a reduction factor $r$, computed as

$r=1-\left(\frac{\left|S-S_{\max }\right|}{S_{\max }}\right)^{2.814}$

with $S$ actual reservoir storage $\left[\mathrm{m}^{3}\right]$ and $S_{\max }$ storage capacity of reservoir $\left[\mathrm{m}^{3}\right]$. With Eq. (1), reservoir evaporation is reduced by $15 \%$ if reservoir storage reaches half the storage capacity and by approximately $50 \%$ if reservoir storage has decreased to $20 \%$ of storage capacity.

For 900 of the 1074 global reservoirs (and regulated lakes), information was available on the main purpose of the reservoir, either irrigation (249) or others (651). For the remaining 174 water bodies, the main purpose was estimated based on consumptive irrigation water use in the five grid cells downstream of the reservoir. If this value use was larger than the $75 \%$ quantile of the irrigation water use downstream of the known non-irrigation reservoirs, the reservoir was assumed to be an irrigation reservoir. Six of the 1074 reservoirs had a negative sum of inflow and vertical reservoir water balance in WGHM and had to be treated as natural lakes. 
The performance of the reservoir algorithm in WGHM was tested by comparing time series of observed monthly outflows from reservoirs to modeled values, distinguishing four cases: reservoirs modeled according to the described reservoir algorithm (ANT), reservoirs modeled as lakes (ANT LAKE), no reservoirs modeled but consumptive water use taken into account (USE), and naturalized conditions without reservoir and use (NAT). The observed reservoir outflow data were obtained from Hanasaki et al. (2006) and included 29 reservoirs with more than 10 years of data that are mostly located in USA and Canada. Ten of the reservoirs are mainly used for irrigation. The best correspondence to observed reservoir outflows is achieved with ANT (i.e. with the reservoir algorithm) for 9 out of 10 irrigation reservoirs (Fig. 3b) and for 15 out of 19 non-irrigation reservoirs (Fig. 3a). If these reservoirs are modeled like lakes, model performance is mostly better than if it is assumed that there is no surface water body at all (USE and NAT). However, for many reservoirs the discrepancies between modeled and simulated monthly outflows remain high, due to erroneously modeled reservoir inflows. For simplicity of analysis, water use for 2002 and not the mostly lower values during the observation years were taken into account, which is not expected to have a significant impact on the analysis. The root mean squared errors shown in Fig. 3 are larger than those of Hanasaki et al. (2006), as Hanasaki and colleagues applied observed and not modeled river discharge as input to their reservoir model.

The effect of the reservoir algorithm on the quality of computed monthly river discharge at the 1235 tuning stations was investigated by comparing the modeling efficiencies (also called Nash-Sutcliffe coefficients) for a model run using the reservoir algorithm $\left(\mathrm{ME}_{r}\right)$ and a model run where reservoirs were modeled as lakes $\left(\mathrm{ME}_{l}\right)$. Monthly time series of observed river discharge were provided by the Global Runoff Data Centre (http://grdc.bafg.de). ME is defined as the mean squared error normalized by the variance of the observed data subtracted from unity, and ranges from minus infinity to one (Janssen and Heuberger, 1995). While a ME-value of one represents a perfect fit of simulated and observed time series, values below zero indicate that the average of observed discharge would be a better estimation than the model. ME represents model success with respect to the mean as well as to the variance of the observations. Among the 937 stations with $\mathrm{ME}_{r}>0$, the modeling efficiencies differed by less than 0.1 for 836 stations, due mostly to the nonexistence of large reservoirs upstream. $\mathrm{ME}_{r}$ was $0.1-0.3$ units better than $\mathrm{ME}_{l}$ at 32 stations and $0.3-0.5$ units better at 36 stations. However, the reservoir algorithm caused a ME decrease of $0.1-0.3(0.3-0.5)$ at $27(6)$ stations.
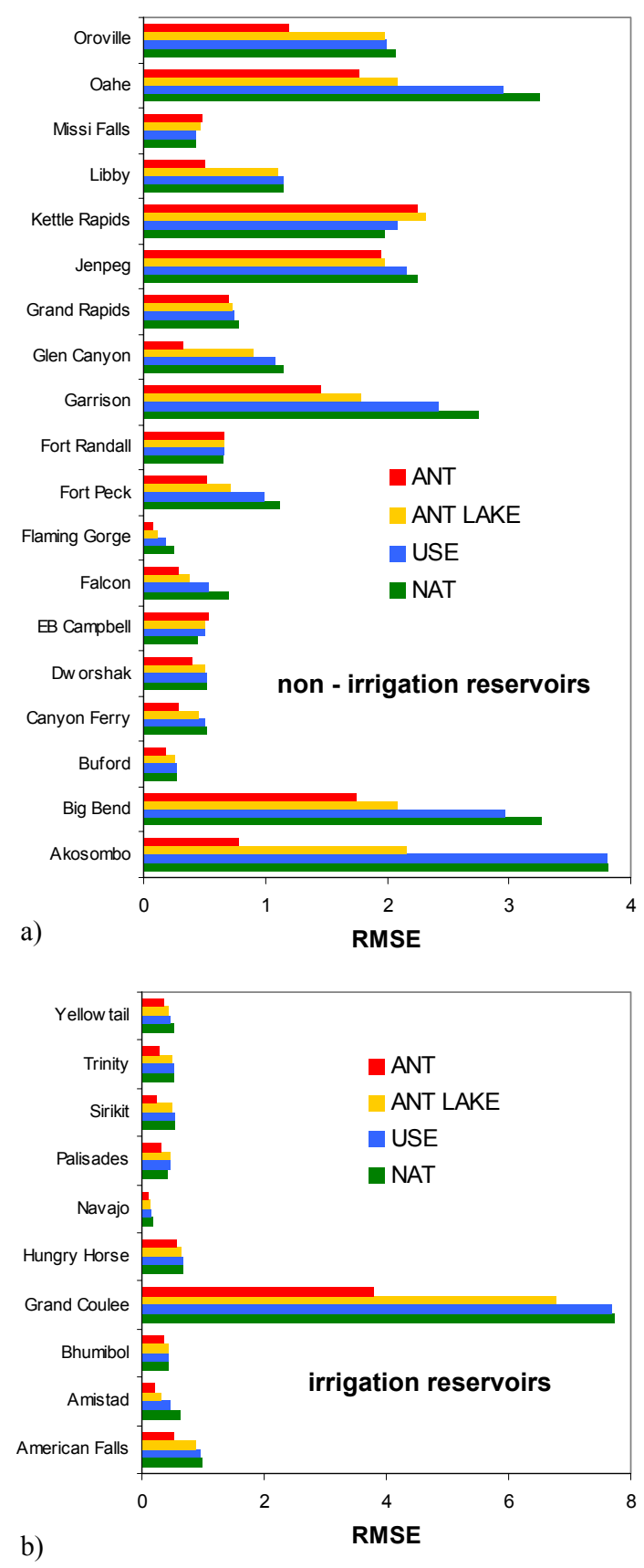

Fig. 3. Validation of WGHM reservoir algorithm against observed reservoir outflow for non-irrigation reservoirs (a) and irrigation reservoirs (b). Outflow data from Hanasaki et al. (2006). RMSE: root mean squared error.

\subsection{Indicators of river flow regime alteration}

We developed six different indicators of river flow regime alteration that are ecologically relevant and can be computed by WGHM in a rather reliable manner (Table 2). The Indicators of Hydrologic Alteration set of Richter et al. (1997) was developed to guide the operation of individual reservoirs. 
Table 2. Six ecologically relevant indicators of river flow alterations due to human water withdrawals and reservoirs.

\begin{tabular}{|c|c|c|c|}
\hline indicator & question & definition & ecological relevance \\
\hline $\mathrm{I}_{\mathrm{LTA}}$ & $\begin{array}{l}\text { How are long-term average river } \\
\text { flows affected? }\end{array}$ & $\begin{array}{l}\text { differences between long-term average } \\
\text { annual river discharges under anthro- } \\
\text { pogenically impacted and naturalized } \\
\text { conditions, in percent of long-term aver- } \\
\text { age annual river discharge under natural- } \\
\text { ized conditions }\end{array}$ & 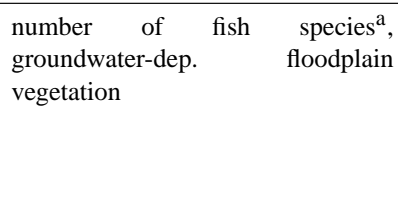 \\
\hline $\mathrm{I}_{\mathrm{LF}}$ & $\begin{array}{l}\text { How are statistical low flows } \\
\text { affected? }\end{array}$ & $\begin{array}{l}\text { difference between } Q_{90} \text { (monthly river } \\
\text { discharge that is exceeded in } 9 \text { out of } \\
10 \text { months) under anthropogenically im- } \\
\text { pacted and naturalized conditions, in per- } \\
\text { cent of } Q_{90} \text { under naturalized conditions }\end{array}$ & $\begin{array}{l}\text { habitat conditions, connectivity } \\
\text { channel/floodplain, } \\
\text { dilution }^{b}\end{array}$ \\
\hline $\mathrm{I}_{\mathrm{SA}}$ & $\begin{array}{l}\text { How is the seasonal amplitude } \\
\text { affected? }\end{array}$ & $\begin{array}{l}\text { difference in seasonal amplitude (max- } \\
\text { imum minus minimum long-term aver- } \\
\text { age monthly river discharge) under an- } \\
\text { thropogenically impacted and naturalized } \\
\text { conditions, in } \% \text { of amplitude under natu- } \\
\text { ralized conditions }\end{array}$ & $\begin{array}{l}\text { habitat availability in particular on } \\
\text { floodplains }\end{array}$ \\
\hline $\mathrm{I}_{\mathrm{SR}}$ & $\begin{array}{l}\text { How is the seasonal regime } \\
\text { affected? }\end{array}$ & $\begin{array}{l}\text { mean over } 12 \text { monthly values of absolute } \\
\text { differences between under anthropogeni- } \\
\text { cally impacted and naturalized condi- } \\
\text { tions in } \% \text { of discharge long-term aver- } \\
\text { age monthly river discharges under natu- } \\
\text { ralized conditions }\end{array}$ & $\begin{array}{l}\text { habitat conditions, compatibility } \\
\text { with life cycle of organisms }\end{array}$ \\
\hline $\mathrm{I}_{\mathrm{TS}}$ & $\begin{array}{l}\text { What seasonal flow shifts have } \\
\text { occurred? }\end{array}$ & $\begin{array}{l}\text { temporal shift of month with maximum } \\
\text { river discharge, in months (if negative, } \\
\text { this month occurs earlier due to anthro- } \\
\text { pogenic impact) }\end{array}$ & $\begin{array}{l}\text { compatibility with life cycle of or- } \\
\text { ganisms }\end{array}$ \\
\hline $\mathrm{I}_{\mathrm{IV}}$ & $\begin{array}{l}\text { How is the interannual variability of } \\
\text { monthly flows affected? }\end{array}$ & $\begin{array}{l}\text { number of months (Jan, Feb, etc.) in } \\
\text { which the coefficient of variation of } \\
\text { monthly flows increases minus the num- } \\
\text { ber of months in which it decreases }(-12 \text {, } \\
-10,-8, \ldots,+8,+10,12) \text { under anthro- } \\
\text { pogenically impacted conditions as com- } \\
\text { pared to naturalized conditions }\end{array}$ & $\begin{array}{l}\text { habitat conditions for aquatic organ- } \\
\text { isms }\end{array}$ \\
\hline
\end{tabular}

\footnotetext{
${ }^{\text {a }}$ Xenopoulos et al. (2005)

b Gibson et al. (2005)

${ }^{\mathrm{c}}$ Computed only for cells in which the coefficient of variation changes by at least $10 \%$ in any month.
}

In these cases, daily discharge measurements are generally available. Therefore, most of the 32 indicators proposed by Richter and colleagues require daily discharges and thus cannot be computed well by a global hydrological model that is driven by monthly climate data. Therefore, we only considered indicators that are based on monthly and annual river discharge estimates. Please note, however, that nevertheless the uncertainty of the computed indicators is very high. When comparing observed to simulated (ANT) values of the flow regime indicators used to derive the indicators of river flow alteration ( $Q_{90}$ as well as mean and interannual variability of monthly flows), the fit is good in some basins and bad in others, often depending on the applied global precipitation data set.
Indicator $\mathrm{I}_{\mathrm{SR}}$ is taken from Black et al. (2005; their indicator 1a), while $\mathrm{I}_{\mathrm{TS}}$ is similar to indicator 3a of Black et al. (2005) but applied for monthly instead of daily discharge values. Black and colleagues also suggested looking not only at the changes of mean values between natural and anthropogenic conditions, but also on the changes of the coefficient of variation. We adapted this idea when we devised indicator IV.

\subsection{Estimation of decrease of freshwater fish richness}

Xenopoulos et al. (2005) derived a regression equation between the number of freshwater species in river basins and the long-term average river discharge (1961-1990) at the mouth of the basins. They considered data from 237 river 
basins located between $42^{\circ} \mathrm{N}$ and $42^{\circ} \mathrm{S}$. The number of fish species mainly relates to endemic fish, with nonindigenous species being assumed to be less than 5\%. Long-term average discharge was computed with a previous version of WGHM (Xenopoulos et al., 2005). Fish species numbers in river basins were found to decrease with decreasing longterm average river discharge according to

Log number of fish species in basin=

$0.4 \cdot \log$ mean annual discharge at basin outlet $\left(\mathrm{m}^{3} / \mathrm{s}\right)$

$+0.6242, r^{2}=0.57$

Xenopolous et al. (2005) used Eq. (2) to predict decreases of fish species richness due to future climate change and future water withdrawals. Here, we applied the regression equation to translate indicator $\mathrm{I}_{\text {LTA }}$ into a direct indicator of a change in the biotic component of freshwater ecosystems. We computed how fish species richness under naturalized flow conditions has decreased due to human water withdrawals and reservoirs, providing estimates for the upstream basin of each $0.5^{\circ}$ grid cell.

\section{Results}

\subsection{Anthropogenic impact on long-term annual average discharge ( $\left.\mathbf{I}_{\text {LTA }}\right)$}

Total discharge into oceans and internal sinks is computed to be $38164 \mathrm{~km}^{3} / \mathrm{yr}$ under anthropogenically altered conditions (ANT), compared to $39549 \mathrm{~km}^{3} / \mathrm{yr}$ for naturalized conditions (NAT) (climate normal 1961-1990, without Antarctica). Thus, dams and water withdrawals (in 2002) have lead to a decrease of global river discharge of $3.5 \%$ and a corresponding increase in evapotranspiration. Water withdrawals alone (USE) would have caused a discharge decrease of $2.7 \%$, while dams alone (RES) would have led to $0.8 \%$ less discharge.

Figure 4 shows naturalized long-term annual river discharge (Fig. 4a) as well the $\mathrm{I}_{\text {LTA }}$ indicator (Fig. 4b). I ITA indicates that long-term average annual discharge (1961-90) has decreased due to anthropogenic impacts, with decreases reaching up to $100 \%$ of natural discharge. The most affected areas are the western and central USA, Mexico, the western coast of South America, the Mediterranean rim, Southern Africa, the semi-arid and countries of the Near East and Western Asia, Pakistan and India, Northern China and the Australian Murray-Darling Basin. Both reservoirs (Fig. 4c) and human water use (Fig. 4d) have led to a decrease of discharge. According to WGHM, the damming of a few lakes (e.g. Lake Baikal in Russia) has caused a small increase of discharge compared to the situation without a dam, i.e. if they are modeled like natural lakes (Fig. 4c). This is related to the different water level variations in case of reservoirs and natural lakes, which lead to different evaporation values.
Water withdrawals are by far the dominant reason for the anthropogenic decrease of long-term average annual river discharge, the areas of strong decrease (high negative values, Fig. 4d) coinciding with the areas of high consumptive water use (Fig. 2a). An exception is humid Southeast Asia, where high consumptive irrigation uses do not lead to high $\mathrm{I}_{\text {LTA }}$ values because river discharge values are high. Globally, $16 \%$ of the global land area (not considering Greenland and Antarctica) suffer from an anthropogenic decrease of longterm average annual river discharge of at least $10 \%$ of the naturalized value (Table 3 ). With " $16 \%$ of the global land" area we mean that $0.5^{\circ}$ grid cells that cover $16 \%$ of the global land are affected by such a decrease. In these areas, the average discharge decrease amounts to $35 \%$ (Table 3), and not only river water levels but also groundwater levels in the adjacent floodplains are expected to be significantly decreased, negatively affecting riparian vegetation. Based on the work by Xenopolous et al. (2005), we expect that the decrease of long-term average river discharge has led to a decrease in the number of endemic fish species (comp. Sect. 3.7).

\subsection{Anthropogenic impact on statistical monthly low flow $Q_{90}\left(\mathbf{I}_{\mathbf{L F}}\right)$}

Naturalized statistical monthly low flow $Q_{90}$ is zero in many arid grid cells (Fig. 5a). Reservoirs and withdrawals have led to wide-spread decreases of $Q_{90}$ (negative $\mathrm{I}_{\mathrm{LF}}$ ) but also increases along some rivers (Fig. 5b). The increases are caused by reservoirs or the regulation of natural lakes (Fig. 5c), as dams generally have the purpose to make river flow temporally more homogeneous to allow for hydropower production, flood protection or water supply. Examples are the Nile just downstream of Lake Victoria, which is regulated by a dam for hydropower production, but also the northern Nile where low flows have been increased by five dams in Ethiopia as well as by the Aswan Dam. The effects of a large number of dams are visible in India, Southeastern Africa, Spain and in the USA. Some reservoirs in semi-arid regions have led to a decrease of $Q_{90}$ (positive $\mathrm{I}_{\mathrm{LF}}$ ) because the additional open water surfaces cause higher evaporation (Fig. 5c). This has decreased long-term average discharge so much that temporal homogenization of discharge cannot balance this decrease. The negative impact of water withdrawals on $Q_{90}$ is larger than the impact on long-term average discharge if expressed in \% decrease from naturalized conditions (comp. Figs. 5d and 4d). The main reason for this is that $Q_{90}$ values are smaller than long-term average discharge values. Decreases have a particular negative impact on habitat availability. Globally, $Q_{90}$ has decreased by, on average, $57 \%$ on $26 \%$ of the land area, mostly due to human water use. It has increased, by at least $10 \%$, on $5 \%$ of the land area, due to reservoirs, with an average increase of $161 \%$ as compared to naturalized conditions (Table 3). 
$\mathrm{a}$

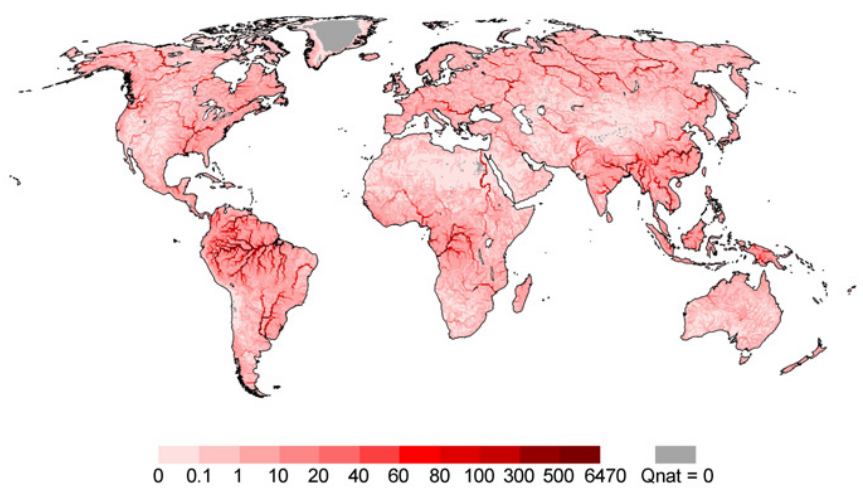

C

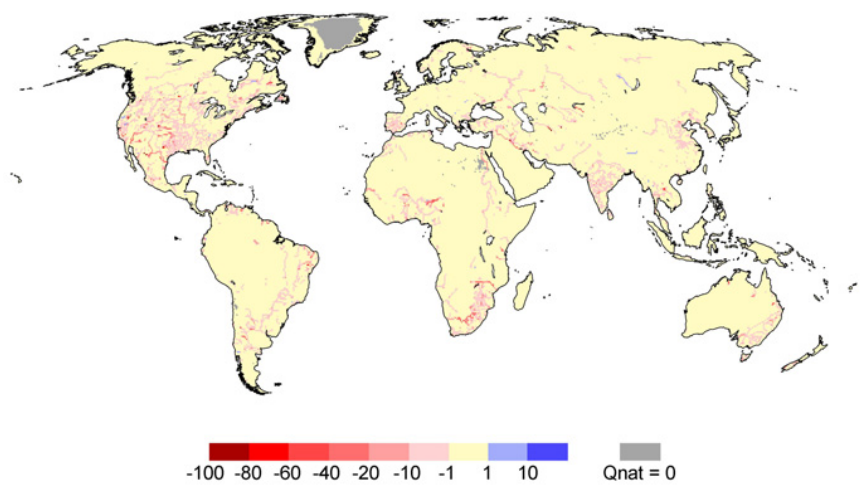

b

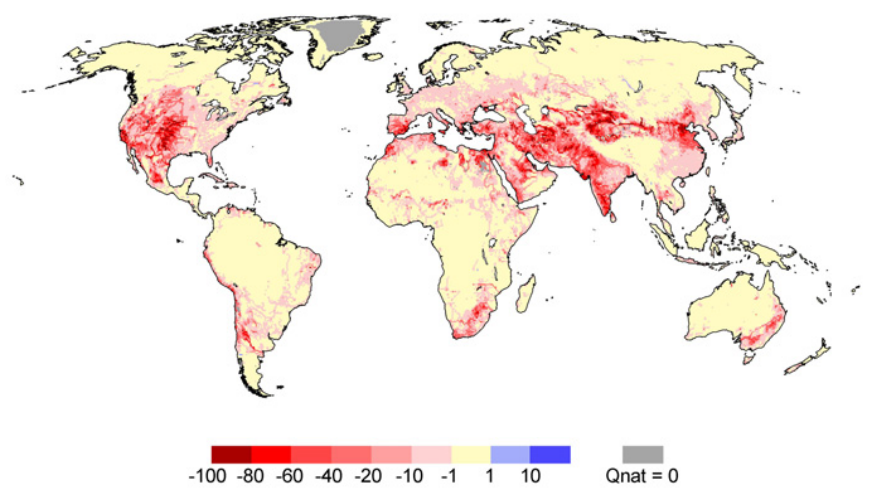

d

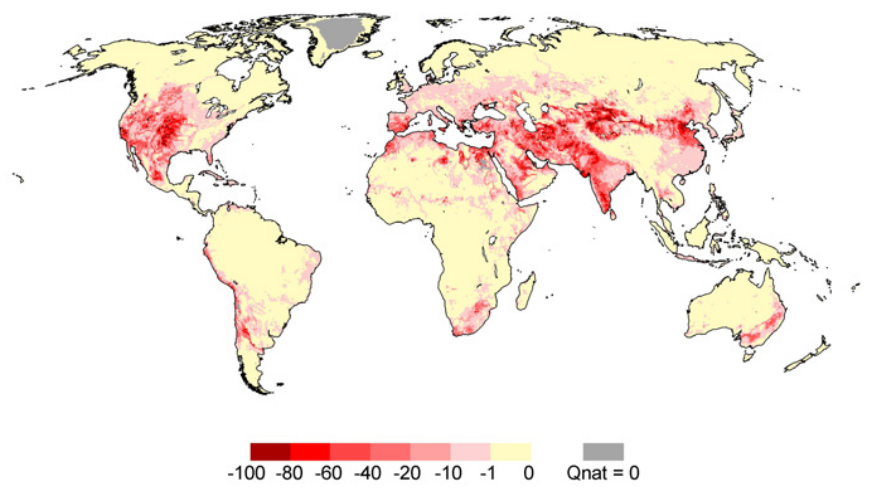

Fig. 4. Anthropogenic impact on long-term average (1961-90) annual river discharges, $\mathrm{I}_{\mathrm{LTA}}$ : naturalized river discharge NAT, in $\mathrm{km}^{3} / \mathrm{yr}$ (a), impact of water withdrawals and reservoirs (ANT): difference between ANT and NAT, in \% of NAT (b), impact of reservoirs only (RES): difference between RES and NAT, in \% of NAT (c), and impact of water withdrawals only (USE): difference between USE and NAT, in \% of NAT (d). $Q$ nat=0: naturalized river discharge value is equal to zero.

Table 3. Global characterization of anthropogenic river flow regime alteration using six indicators (ANT compared to NAT). Greenland and Antarctica are not taken into account.

\begin{tabular}{|c|c|c|c|c|}
\hline \multirow[t]{2}{*}{ indicator } & \multicolumn{2}{|c|}{$\begin{array}{l}\% \text { of land area with indicator value } \\
\geq|10 \%| \text { (or } \geq \mid 1 \text { month } \mid \\
\left.\text { in case of indicators } \mathrm{I}_{\mathrm{TS}} \text { and } \mathrm{I}_{\mathrm{IV}}\right)\end{array}$} & \multicolumn{2}{|c|}{$\begin{array}{c}\text { average indicator values for } \\
\text { these land areas, in } \% \\
{\text { (for indicators } \mathrm{I}_{\mathrm{TS}} \text { and } \mathrm{I}_{\mathrm{IV}} \text { in months) }}^{\mathrm{a}}\end{array}$} \\
\hline & increase & decrease & increase & decrease \\
\hline $\mathrm{I}_{\mathrm{LTA}}$ & 0.002 & 16.2 & 18.2 & -34.8 \\
\hline $\mathrm{I}_{\mathrm{LF}}$ & 4.9 & 26.0 & 161.4 & -57.1 \\
\hline $\mathrm{I}_{\mathrm{SA}}$ & 0.6 & 14.8 & 25.7 & -38.6 \\
\hline $\mathrm{I}_{\mathrm{SR}}{ }^{\mathrm{b}}$ & \multicolumn{2}{|c|}{23.8} & \multicolumn{2}{|c|}{41.8} \\
\hline $\mathrm{I}_{\mathrm{TS}}$ & 2.7 & 1.7 & 1 & -2 \\
\hline $\mathrm{I}_{\mathrm{IV}}$ & 26.8 & 7.5 & 10 & -5 \\
\hline
\end{tabular}

a cell area weighted average of grid cell values

$\mathrm{b}$ indicator has absolute values 
a

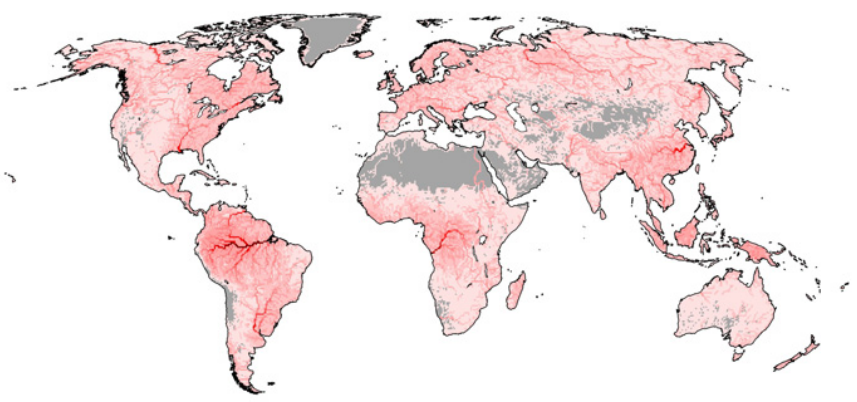

$\begin{array}{llllllllllll}0 & 0.01 & 0.1 & 1 & 5 & 10 & 20 & 40 & 60 & 80 & 100 & 316\end{array}$ Qnat $=0$

C

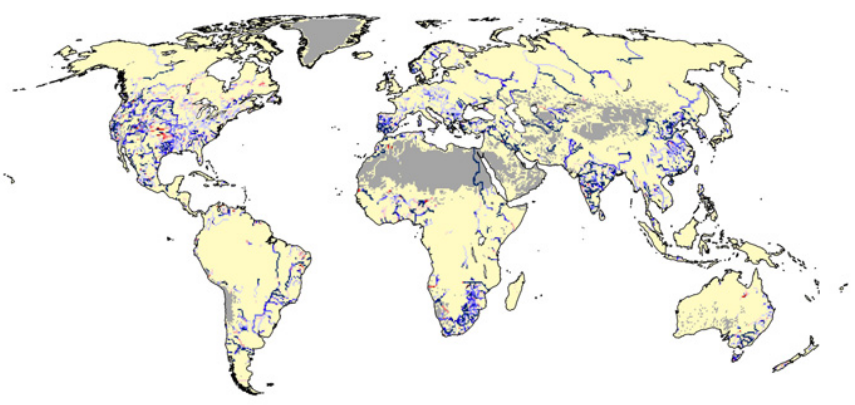

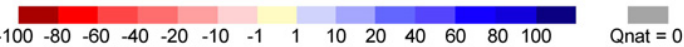

b

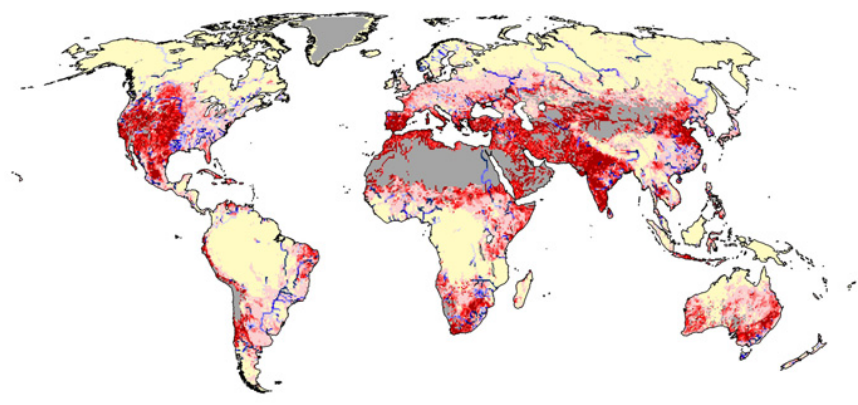

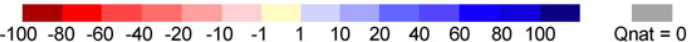

d

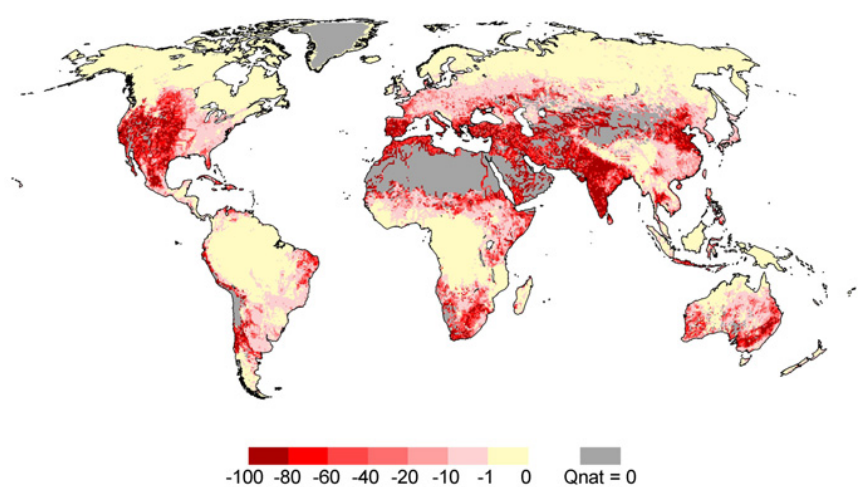

Fig. 5. Anthropogenic impact on long-term average (1961-90) monthly low flows $Q_{90}, \mathrm{I}_{\mathrm{LF}}$ : naturalized $Q_{90}$, in $\mathrm{km}^{3} / \mathrm{month}$ (a), impact of water withdrawals and reservoirs (ANT): difference between ANT and NAT, in \% of NAT (b), impact of reservoirs only (RES): difference between RES and NAT, in \% of NAT (c), and impact of water withdrawals only (USE): difference between USE and NAT, in \% of NAT (d). $Q$ nat=0: naturalized river discharge value is equal to zero.

\subsection{Anthropogenic impact on amplitude of seasonal variability of long-term average monthly discharges (ISA)}

Due to reservoirs and human water withdrawals, the difference between the minimum and the maximum long-term average monthly discharge decreases downstream of reservoirs and in areas with high consumptive water use (Fig. 6a). It increases slightly in areas with low water use, or downstream of some regulated lake where regulation leads to a less smooth outflow (e.g. Lake Baikal and Lake Victoria). Seasonal amplitudes decrease mainly because of a decrease in high flows, either due to outflow reductions by dams or high consumptive water use during the high flow months. Such a decrease has negative impacts on, for example, the flora and fauna of seasonally flooded floodplains. The decrease of seasonal amplitude due to reservoirs is consistent with the results of Poff et al. (2007) who analyzed the impact of 186 reservoirs in the continental USA, and with observations for
Arctic rivers (e.g. Yang et al., 2004). Globally, the seasonal amplitude decreases on $15 \%$ of the land area by at least $10 \%$ compared to natural conditions, by on average $39 \%$. It increases by at least $10 \%$ on less than $1 \%$ of the land area, by on average $26 \%$ (Table 3 ).

\subsection{Anthropogenic impact on seasonal flow regime ( $\left.\mathbf{I}_{\mathrm{SR}}\right)$}

Different from $\mathrm{I}_{\mathrm{SA}}$, the indicator $\mathrm{I}_{\mathrm{SR}}$ does not look only at the months with the highest and lowest flows but considers the anthropogenic changes of all 12 long-term average monthly river discharge values. $\mathrm{I}_{\mathrm{SR}}$ may range between $0 \%$ and infinity because for this indicator, absolute differences of the monthly discharges under naturalized and anthropogenic differences, in percent of the naturalized monthly flows, are averaged over all 12 months. On almost one quarter of the global land area, ISR is $10 \%$ or larger, while the average $\mathrm{I}_{\mathrm{SR}}$-value for this area is $42 \%$ (Table 3 ). There, natural seasonal flow variability has been altered significantly, with negative impacts on habitat availability and the compatibility of 


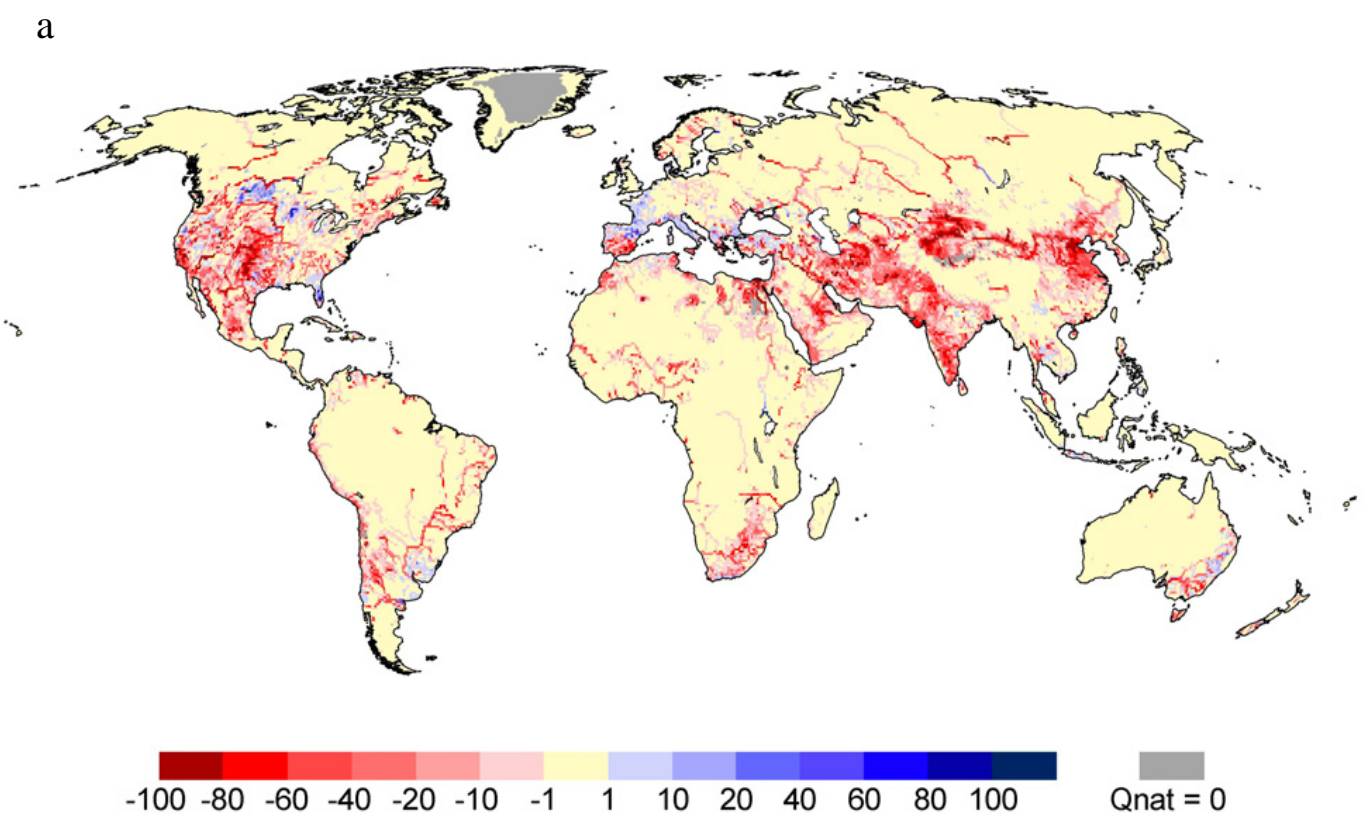

b
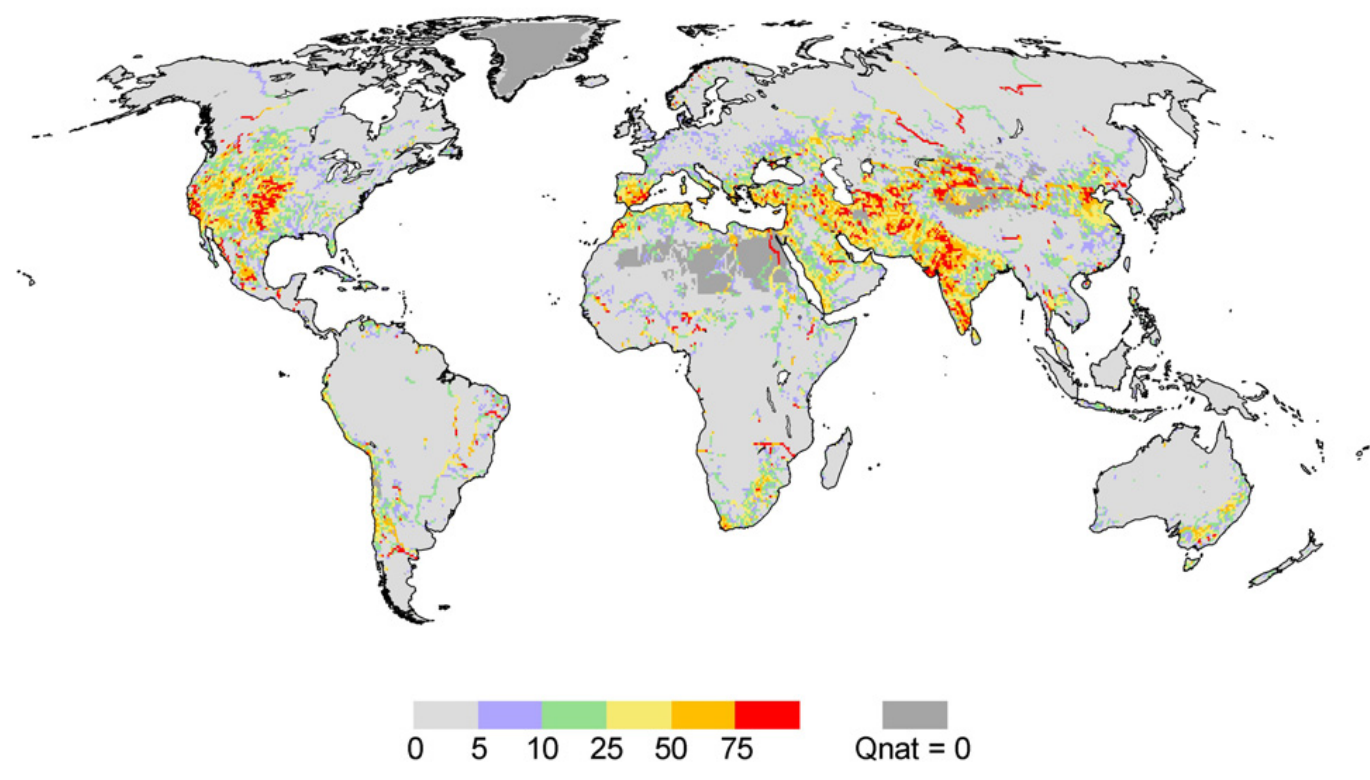

Fig. 6. Anthropogenic impact on seasonal flow amplitudes, ISA, in \% of NAT (a), and on seasonal flow regimes, ISR, in $\%$ of NAT (b). $Q$ nat=0: naturalized river discharge value is equal to zero.

the flow regime with the life cycle of aqueous organisms. Figure $6 \mathrm{~b}$ shows the spatial distribution of the indicator. Both reservoirs and high consumptive water use can cause large changes in the seasonal flow regime, but the impact of consumptive water use is more diffuse and often stronger than the impact of reservoirs.

\subsection{Anthropogenic shift of month with maximum discharge ( $\left.\mathbf{I}_{\mathrm{TS}}\right)$}

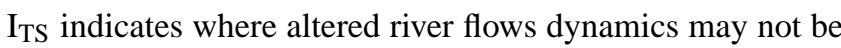
compatible with the life cycle of organisms any more. A shift in the seasonal occurrence of the maximum mean monthly discharge value of at least one month occurs rather seldom 
and is almost exclusively due to reservoir operations (Fig. 7a, compare to Fig. 5c). On almost 3\% of the land area, maximum seasonal flows occur at least one month later than under naturalized conditions, and on almost $2 \%$ of the land area at least one month earlier, with typical shifts of 1 to 2 months (Table 3 ). The USA is particularly affected by temporal shifts of the occurrence of high flows (Fig. 7a).

\subsection{Anthropogenic impact on interannual variability of monthly flows (IIV)}

Interannual variability of monthly mean flows, as expressed by the coefficient of variation, increases significantly wherever there is an even small consumptive water use (Figs. 7b and 1a). Please note that $I_{I V}$ is computed only for cells in which the coefficient of variation changes by at least $10 \%$ in any month. In years with low precipitation and thus low natural discharge, discharge is strongly decreased by higher than normal consumptive water use for irrigation. In years with high precipitation and natural discharge, discharge is less strongly decreased, as a high precipitation amount leads to a lower than normal irrigation water use. Therefore, irrigation increases interannual variability of river discharge such that $\mathrm{I}_{\mathrm{IV}}$ is positive in irrigation areas. But even the temporally constant consumptive water use assumed for households and industry leads to an increase of $\mathrm{I}_{\mathrm{IV}}$, as the coefficient of variation increases with decreasing mean. Interannual variability decreases only downstream of dams where there is no high consumptive water use (Fig. 7b). The latter is consistent with the findings of Poff et al. (2007) for the USA.

On more than one quarter of the land area, the number of months in which interannual variability increases is larger than the number of months for which interannual variability decreases due to anthropogenic impacts. For these cells, variability increases, on average, for 11 out of 12 months $\left(I_{\mathrm{IV}}=11+(-1)=10\right.$, Table 3$)$. On less than $8 \%$ of the land area, interannual variability predominantly decreases, during 8 to 9 months on average (Table 3 ).

\subsection{Effect of anthropogenically decreased long-term average river flows on the number of fish species}

Due mainly to water withdrawals, long-term annual river discharge has decreased as compared to natural conditions (Sect. 3.1), and it can be expected that this decrease has lead to a decrease of endemic fish species (Xenopoulos et al., 2005). Using Eq. (2), the decrease in the number of fish species upstream of each grid cell due to water withdrawals and dams, in \% of fish species that would exist under naturalized long-term average river discharge, was computed (Fig. 8). High decreases of fish species of up to $99 \%$ may have occurred according to this rough estimation, with the highest decreases in areas with a very high decrease of longterm average discharge due to water withdrawals (Fig. 4d and Sect. 3.1). On 10\% of the land area, the number of fish species in the upstream basin has decreased by at least $10 \%$, while on $0.6 \%$, it has decreased by even $50 \%$ and more. The average decrease in areas with at least a $10 \%$ decrease is $24 \%$. We believe that the computed fish species reduction is much smaller than in reality as only the changes of annual river discharge are taken into account, but not the changes at the monthly scale.

\section{Discussion}

Our study has indicated significant flow alterations in regions with high consumptive water use (i.e. irrigation areas) and downstream of dams. The question is: how well can we estimate river flow alterations due to human water use and dams with WGHM? As four of the six indicators presented here are based on mean monthly river discharges, we looked at mean monthly river discharge at four gauging stations for which observations and partly also independent estimates of naturalized flows were available. All four stations (Colorado at Lees Ferry, Missouri at Hermann, Volta at Senchi (Halcrow), and Volga at Volgograd Power Station) are tuning stations that are located downstream of large reservoirs, but only the two US basins have considerable consumptive water use (Table 4). For the US basins, local estimates of naturalized river discharge were available for 1980-1999 (Haddeland et al., 2006). Please note that the station "Glen Canyon" in Haddeland et al. (2006) is equivalent to the station "Lees Ferry".

For the Volta at Senchi, we compared long-term monthly river discharge as computed for naturalized conditions (NAT) for the years 1951-1964, i.e. for the time before dam construction, with values that were observed during that time period. In addition, we considered the time period 1968-1984 after dam construction, comparing observations to simulations under anthropogenic impacts (ANT). Figure 9a shows that for the time period after dam construction, the very low observed seasonality of discharge is represented well by WGHM. If Lake Volta is modeled like a natural lake and not a reservoir (ANT LAKE), the fit to the observed discharge is worse, and, for example, discharge in the dry season (February to June) is underestimated. Simulated naturalized discharge, i.e. discharge before dam construction, has a much higher seasonal variability than the anthropogenically impacted discharge, with a peak in September. Observed variability, however, is even larger, with a higher peak that is shifted by one month, and zero flow between February and May. Thus, for this gauging station, WGHM underestimates $\mathrm{I}_{\mathrm{SA}}$ and $\mathrm{I}_{\mathrm{SR}}$, while $\mathrm{I}_{\mathrm{TS}}$ is estimated correctly.

Discharge of the Volga observed at the Volgograd Power Station during the period 1961-90 peaks in May, which is rather well modeled by ANT even though discharge from January to March is somewhat underestimated (Fig. 9b). If the upstream reservoirs are simulated like natural lakes, peak discharge is overestimated, and the impact of reservoirs on peak flow is strongly underestimated (Fig. 9b). Naturalized 
a

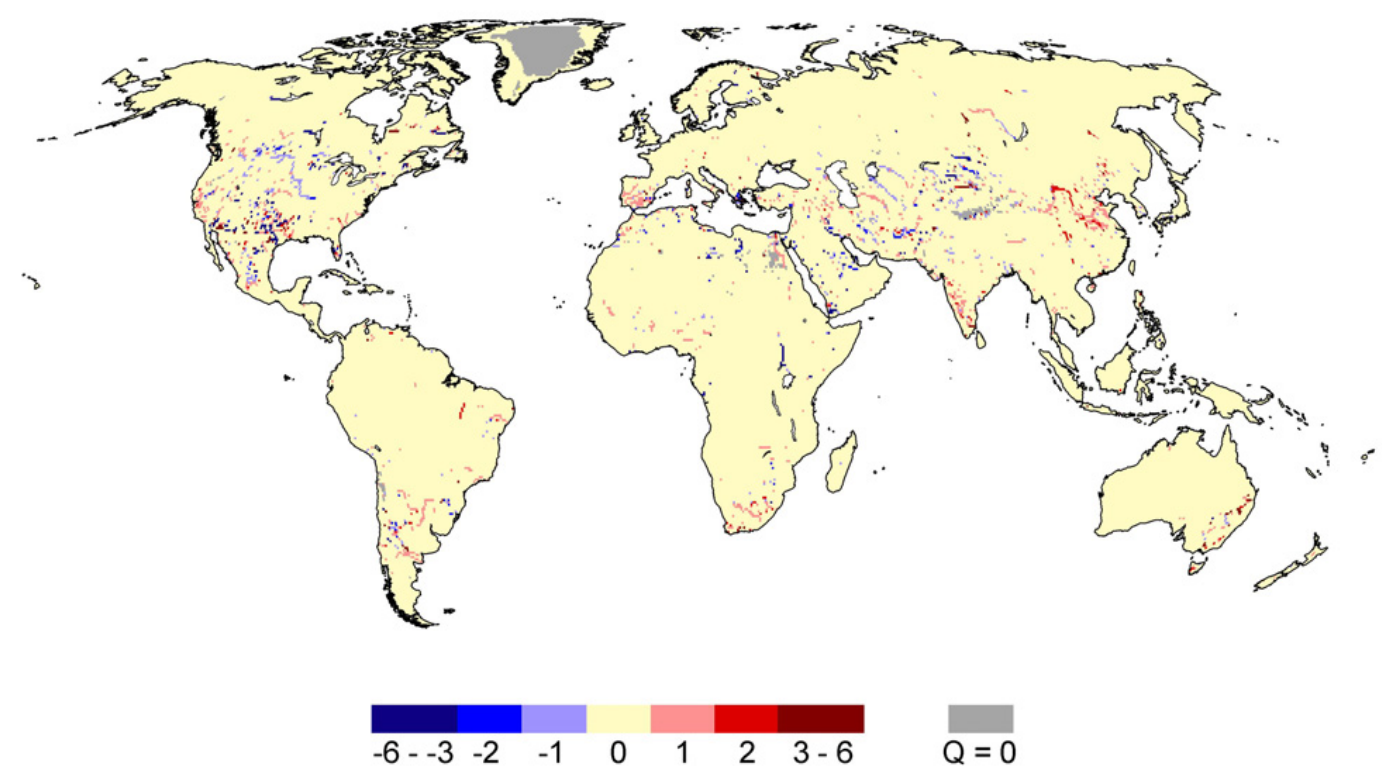

b
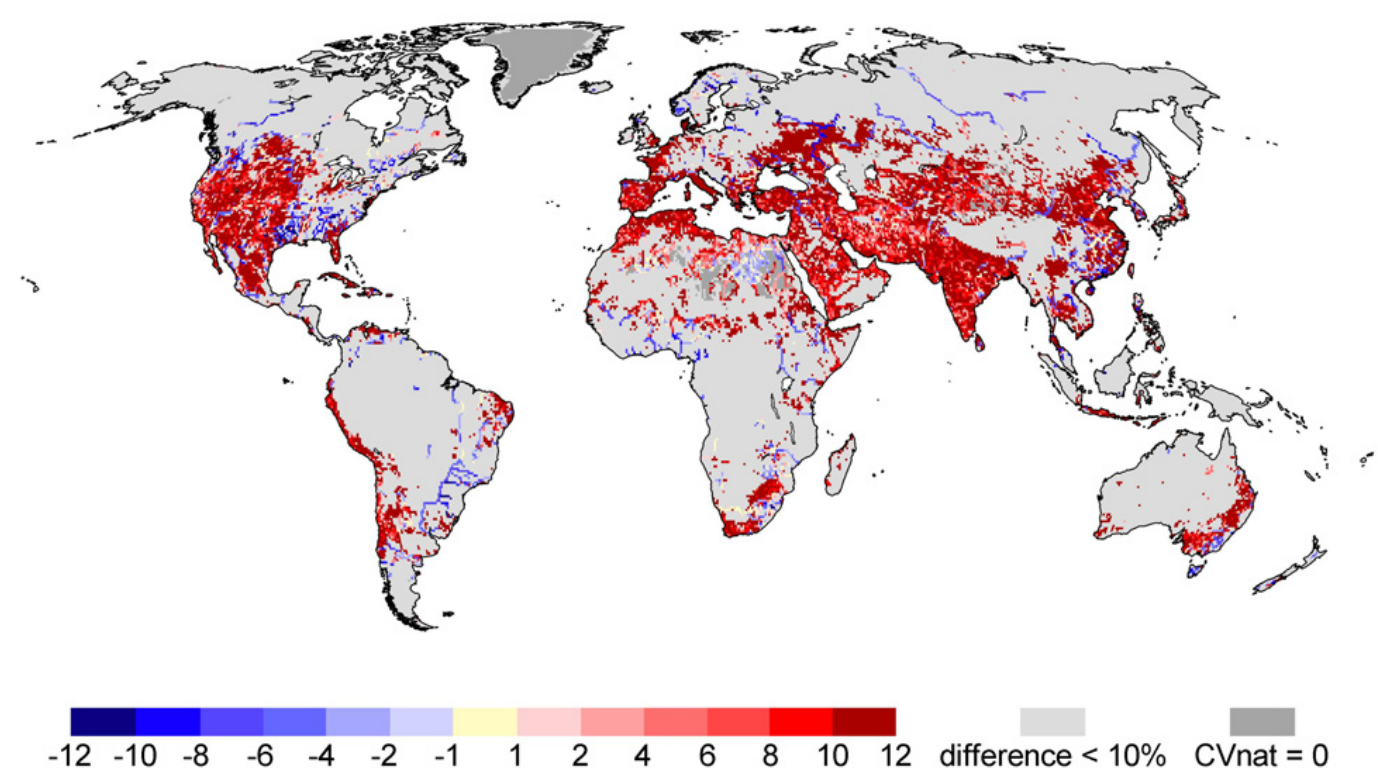

Fig. 7. Anthropogenic shift of the month with maximum flow, $\mathrm{I}_{\mathrm{TS}}$, in months (a), and anthropogenic impact on interannual variability of monthly flows, $\mathrm{I}_{\mathrm{IV}}$, in months (b). If $\mathrm{I}_{\mathrm{IV}}$ is positive, interannual variability increases in most months due to anthropogenic impacts; if $\mathrm{I}_{\mathrm{IV}}$ equals 12 , it increases in each month of the year. $Q$ nat $=0$ : naturalized river discharge is equal to zero. $C V$ nat $=0$ : naturalized coefficient of variation of any of the 12 monthly river discharge values is zero.

discharge is estimated to amount to only half the ANT value from January to March, and it shows a May peak discharge that is 50\% larger than the discharge with reservoirs. Between July and November, reservoir impact is very small.
The hydrographs for the Missouri at Hermann show that WGHM can, for this station, model the anthropogenic impact on the month with maximum flow $\left(\mathrm{I}_{\mathrm{TS}}=1\right)$ well even though the model simulates the peak flows to occur too early for all model variants (Fig. 9c). Like for the Volta, the naturalized 


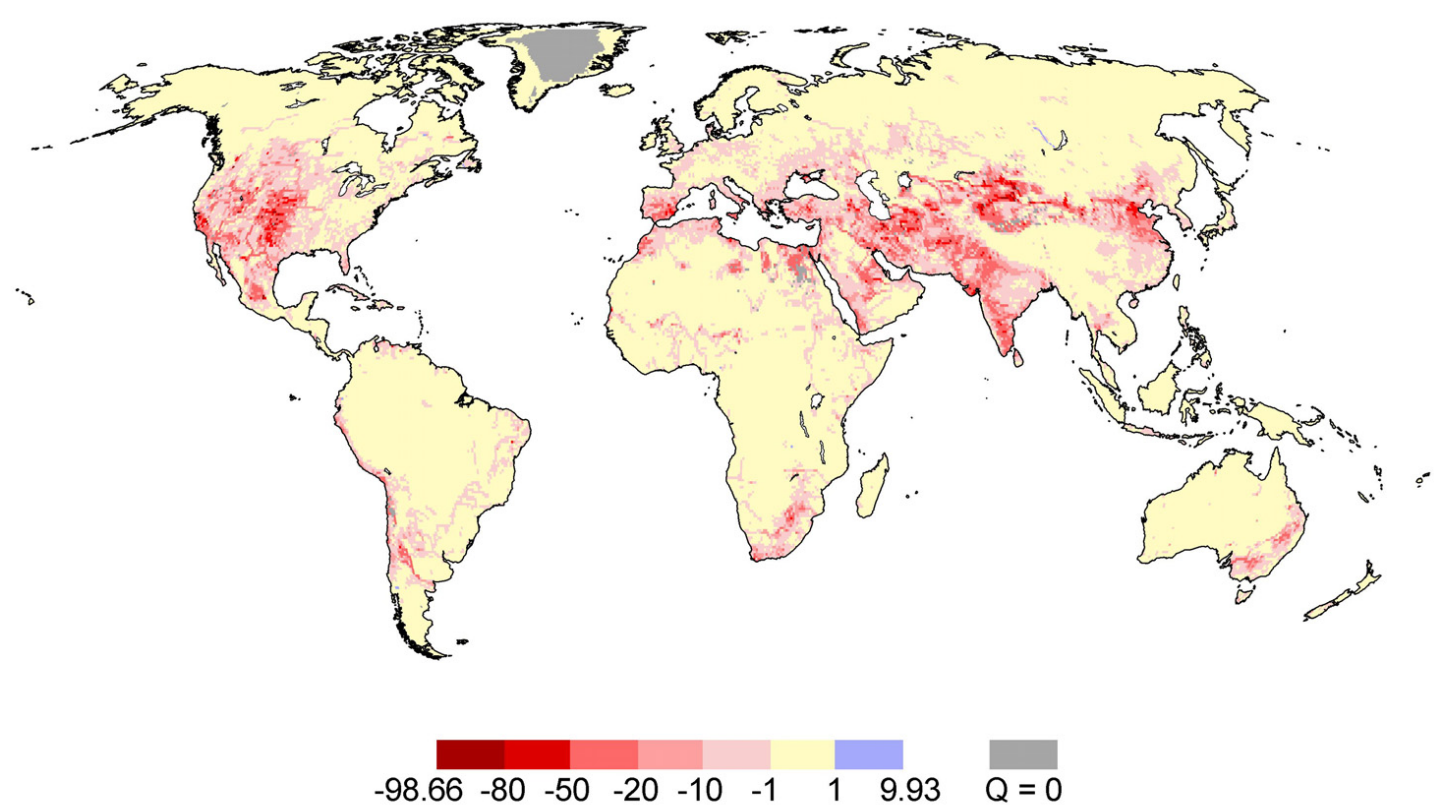

Fig. 8. Change of number of fish species upstream of grid cells due to changes in long-term average discharge caused by water withdrawals and reservoirs, in $\%$ of fish species that would exist under naturalized conditions.
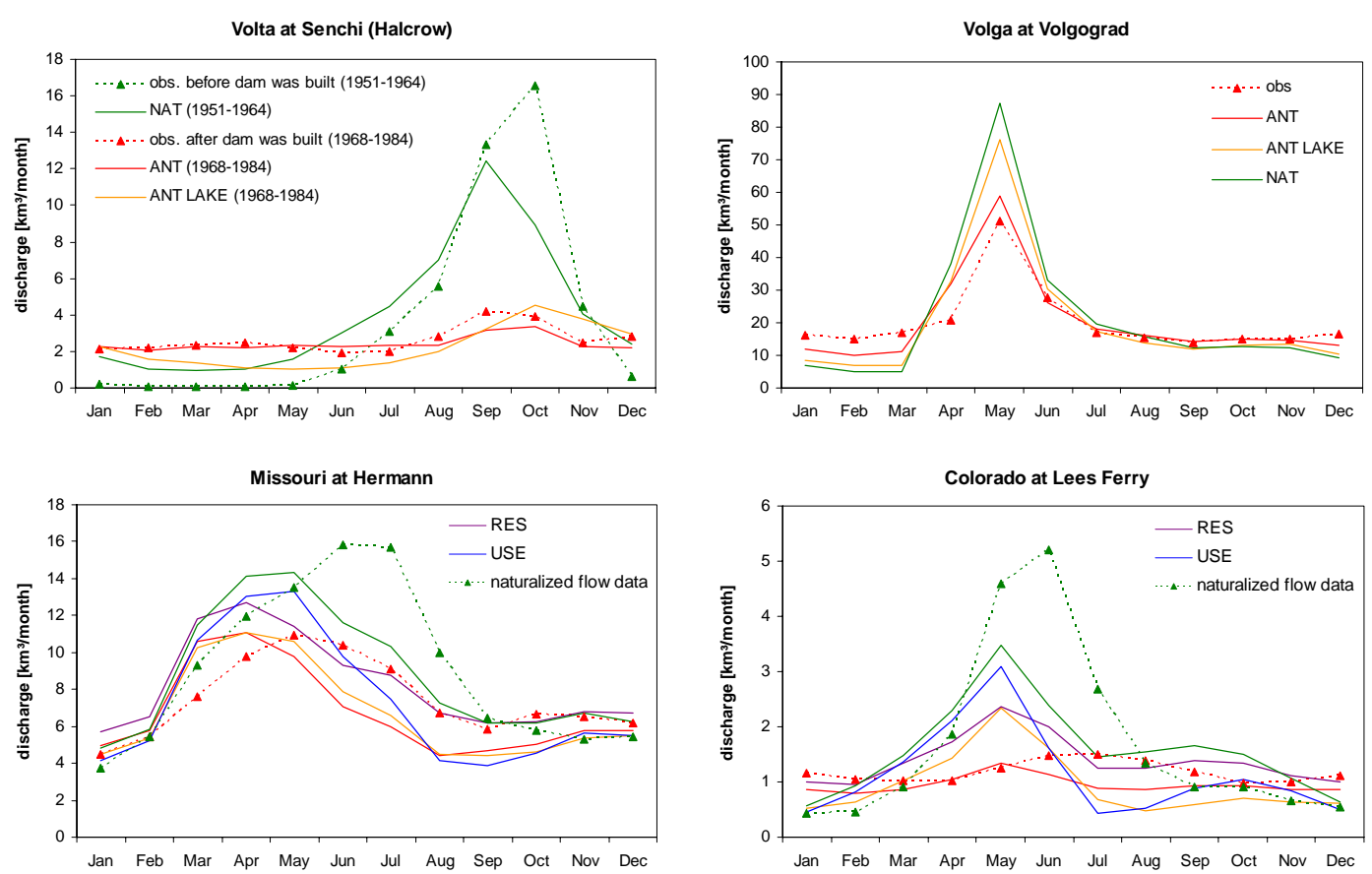

Fig. 9. Long-term average monthly river discharge at four selected gauging stations: comparison between observed and independent estimates of naturalized river discharges, and modeled anthropogenically altered (ANT) and naturalized (NAT) conditions. ANT LAKE refers to a simulation in which the global reservoirs are modeled as lakes, while RES and USE refer to simulations with only reservoirs or only use, respectively. Discharge observations were provided by the Global Runoff Data Centre (grdc.bafg.de), while naturalized discharge data are from Haddeland et al. (2006). Time period for the Colorado and Missouri 1980-1999, for the Volga 1961-1990. Please note that legend for the Volga also applies to Missouri and Colorado. 
Table 4. Characteristics of four selected gauging stations with significant impact of upstream reservoirs or water use: basin and station name, upstream area, observed long-term average river discharge, consumptive use CU in upstream area, reservoir area in \% of upstream area and reservoir storage divided by observed discharge $\left(S / Q_{\text {obs }}\right)$.

\begin{tabular}{llrrrrrr}
\hline basin & station & $\begin{array}{r}\text { tuning } \\
\text { period }\end{array}$ & $\begin{array}{r}\text { upstream } \\
\text { rea }^{\mathrm{a}} \\
{\left[\mathrm{km}^{2}\right]}\end{array}$ & $\begin{array}{r}\text { observed } \\
\text { discharge } \\
{\left[\mathrm{km}^{3} / \mathrm{yr}\right]}\end{array}$ & $\begin{array}{r}\text { CU 2002 } \\
\text { upstream } \\
{\left[\mathrm{km}^{3} / \mathrm{yr}\right]}\end{array}$ & $\begin{array}{r}\text { reservoir } \\
\text { area [\% of } \\
\text { upstream } \\
\text { area }]\end{array}$ & $\begin{array}{c}S / Q_{\text {obs }} \\
{[\mathrm{yr}]}\end{array}$ \\
\hline Colorado & Lees Ferry & $1955-84$ & 288177 & 12.1 & 3.70 & 0.38 & 3.56 \\
Missouri & Hermann & $1958-87$ & 1347425 & 76.1 & 22.76 & 0.45 & 1.25 \\
Volga & Volgograd Power Plant & $1961-90$ & 1363415 & 239.2 & 3.09 & 1.38 & 0.82 \\
Volta & Senchi (Halcrow) & $1955-84$ & 399457 & 32.9 & 0.18 & 2.00 & 4.77 \\
\hline
\end{tabular}

a basin area upstream of gauging station according to WGHM

peak flow is somewhat underestimated by the model which leads to an underestimation of $\mathrm{I}_{\mathrm{SA}}$. Without reservoirs and only water use (USE), discharge would decrease significantly throughout the year as compared to naturalized discharge, while reservoirs but no water use (RES) would lead to increased discharge in winter (January to March) and decreased values during the high flow period from April to August. As upstream water use also affects the simulated reservoir operation, the effects of reservoirs and use are not additive.

Like for the Volta and the Missouri, naturalized seasonal peak flow is underestimated by WGHM for the Colorado at Lees Ferry, while the low seasonal variability of anthropogenically impacted discharge is captured well (Fig. 9d). The observed shift of the month with maximum flow is one month, but zero months for the simulated values. Again, the positive effect of modeling the outflow dynamics of reservoirs differently from those of natural lakes can be observed. Nonetheless, there are also some stations around the globe for which a better fit to observed discharge can be obtained if reservoirs are modeled like natural lakes. Based on the analysis of the four stations, we might conclude that with respect to the indicators $\mathrm{I}_{\mathrm{SA}}$ and $\mathrm{I}_{\mathrm{SR}}$, our WGHM-based analysis underestimates the actual anthropogenic impact. However, due to the very low number of analyzed stations, this conclusion is not robust.

Haddeland et al. (2006) showed a better fit between the naturalized flow regime they computed with the hydrological model and the independent naturalized flow data for the Colorado and the Missouri shown in Fig. 9. This might be due to the fact that they (indirectly) tuned their reservoir algorithm to the naturalized flow data available to them: for the Colorado, the Missouri and the Columbia. Besides, tuning of their hydrological involved more parameters than tuning of WGHM.
With respect to modeling the impacts of reservoirs on discharge dynamics, a major uncertainty is caused by the fact that reservoir operation is done, in reality, in a very sitespecific manner that cannot be simulated very well by a general algorithm in a global-scale model. The actual number of reservoirs, in particular the number of small reservoirs, is much higher than the number of reservoirs represented in WGHM. Therefore, the impact of reservoirs and regulated lakes on river flow regimes is certainly underestimated in this study.

With respect to the impacts of water use, uncertainty is related to uncertain water use estimates, in particular for irrigation. Here, even the location of areas equipped for irrigation is rather uncertain in many areas (Siebert et al., 2005). Besides, water withdrawals are assumed to be taken from surface water or shallow groundwater, such that all water withdrawals lead to a river flow reduction. If, however, deep groundwater without any connection to surface water is withdrawn, river flow might even increase due to the return flow to surface water via artificial drainage or shallow groundwater.

How significant are the anthropogenic changes of river flow regimes caused by water withdrawals and reservoirs as compared to the conversion of potential vegetation to agricultural land? Conversion to agricultural land has lead to decreased evapotranspiration while water use and reservoirs have increased evapotranspiration. Besides, land conversion has affected all agricultural lands and not only the approximately $20 \%$ that are irrigated. Rost et al. (2008) modeled both the impact of land conversion and the impact of water use for the time period 1991-2000. They found that land conversion (without irrigation) has increased global long-term average river discharge by $6.6 \%$ as compared to the discharge for potential vegetation, while irrigation has led to a decrease of $1.5 \%$ as compared to only rainfed agriculture. The latter value differs from our model analysis, where irrigation water 
withdrawals are estimated to result in a decrease of global discharge of approximately $2.4 \%$. The discrepancy between the two model results may be due to the fact that in the model of Rost et al. (2008), delayed satisfaction of water requirements from surface waters, which approximates water withdrawals from renewable groundwater resources, is not implemented, such that a smaller fraction of the water requirements can be fulfilled than in WGHM (see Fig. 1b). In conclusion, decrease of river discharge by total water withdrawals and dams, by 3.5\% as computed in our study, approximately balances half of the discharge increase caused by land conversion, if we consider global averages. However, an aggregation over river basins is more appropriate for ecological questions. Rost et al. (2008) found that in river basins with extensive irrigation the combined effect of land conversion and irrigation water use was a decrease of river discharge, even though they appear to somewhat underestimate the effect of irrigation. Thus, we expect that conversion and water use in semi-arid areas with significant irrigation have lead to an overall decrease of discharge unless deep non-renewable groundwater is the source of water.

\section{Conclusions}

This study has provided a first global overview of the impacts of human water use and dams on river flow regimes. Six different indicators of river flow alteration were identified that are of specific relevance for the health (e.g. biodiversity) of the biotic components of freshwater ecosystems. These indicators describe anthropogenic flow changes that concern organisms in surface waters as well as groundwaterdependent vegetation in floodplains. Applying the state-ofthe-art global water model WaterGAP, which integrates the computation of both human water use and terrestrial water flows and takes into account the impact of more than 6600 dams, these indicators were quantified with a spatial resolution of $0.5^{\circ}$ by $0.5^{\circ}$.

Total long-term average river discharge into oceans and internal sinks has been decreased by $3.5 \%$ due to water withdrawals and dams. One sixth of the global land area (excluding Greenland and Antarctica) has suffered from a significant decrease of long-term average annual river discharge (of more than 10\%), mainly due to water withdrawals and in particular irrigation, which accounts for more than $90 \%$ of global consumptive water use. The average decrease in these areas has been $35 \%$. This decrease in annual river discharge may have lead to a more than $10 \%$ decrease of the number of fish species in the upstream basins of one tenth of the land area. The monthly statistical low flow $Q_{90}$ has decreased significantly on a quarter of the land area, but on $5 \%$ of the land area, downstream of reservoirs, it has increased significantly. Also on one sixth of the land area, seasonal discharge am- plitudes have decreased significantly, both due to reservoirs and water use. While seasonal variability has thus become smaller due to human impacts, interannual variability has increased due to water use except in areas downstream of dams with little consumptive water use. A temporal shift of the month with maximum discharge by at least one month has occurred on only $4 \%$ of the land area. The spatial patterns of significant alterations are roughly the same for all indicators except $\mathrm{I}_{\mathrm{TS}}$, as high indicator values are in most cases related to the spatial patterns of water use and dams.

Identification and quantification of anthropogenic river flow alterations is a first step for defining environmental flow guidelines. The next step would be to develop quantitative relationships between indicators of biotic changes (e.g. species richness, traits, assemblage structure, recruitment success) and degrees of flow alterations (Arthington et al., 2006). Arthington et al. (2006) suggested computing flow alterations either as compared to undisturbed reference streams, or, if these do not exist, by hydrological modeling as done in this study. They also suggested classifying all rivers according to their natural flow regime, such that quantitative relationships determined for a few selected rivers can be applied to rivers for which no ecological data are available. This approach has the potential to lead to scientifically-based environmental flow guidelines even for the majority of global rivers that only have very scarce ecological data. Such guidelines are urgently required to support a sustainable water resources management that balances human and ecosystem water demands.

Acknowledgements. We thank Bernhard Lehner and Ingjerd Haddeland for providing data. We are grateful to Balazs Fekete and two anonymous reviewers for their thoughtful comments. This study was partly funded by the IPSWaT program of BMBF (German Ministry for Education and Research).

Edited by: K. Bishop

\section{References}

Alcamo, J., Döll, P., Henrichs, T., Kaspar, F., Lehner, B., Rösch, T., and Siebert, S.: Global estimates of water withdrawals and availability under current and future "business-as-usual" conditions, Hydrol. Sci. J., 48, 339-348, 2003a.

Alcamo, J., Döll, P., Henrichs, T., Kaspar, F., Lehner, B., Rösch, T., and Siebert, S.: Development and testing of the WaterGAP 2 global model of water use and availability, Hydrol. Sci. J., 48, 317-337, 2003b.

Arthington, A. H., Bunn, S. E., Poff, N. L., and Naiman, R. J.: The challenge of providing environmental flow rules to sustain river ecosystems, Ecol. Appl., 16(4), 1311-1318, 2006. 
Arthington, A. H. and Pusey, B. J.: In-stream flow management in Australia: methods, deficiencies and future directions, Australian Biology, 6, 52-60, 1993.

Avakyan, A. B. and Iakovleva, V.B.: Status of global reservoirs: The position in the late twentieth century, Lakes \& Reservoirs, Research and Management, 3, 45-52, 1998.

Black, A. R., Rowan, J. S., Duck, R. W., Bragg, O. M., and Clelland, B. E.: DHRAM: a method for classifying river flow regime alterations for the EC Water Framework Directive, Aquat. Conserv., 15, 427-446, 2005.

Bouwer, L. M., Aerts, J. C. J. H., Droogers, P., and Dolman, A. J.: Detecting the long-term impacts from climate variability and increasing water consumption on runoff in the Krishna river basin (India), Hydrol. Earth Syst. Sci., 10, 703-713, 2006, http://www.hydrol-earth-syst-sci.net/10/703/2006/.

Chao, B. F., Wu, Y. H., and Li, Y. S.: Impact of artificial reservoir water impoundment on global sea level, Science, 320, 212-214, 2008.

Clausen, B. and Biggs, B. J. F.: Flow variables for ecological studies in temperate streams: groupings based on covariance, J. Hydrol., 237, 184-197, 2000.

Custodio, E.: Aquifer overexploitation: what does it mean? Hydrogeol. J., 10, 254-277, 2002.

Döll, P.: Vulnerability to the impact of climate change on renewable groundwater resources: a global-scale assessment, Environ. Res. Lett., 4, 036006, doi:10.1088/1748- 9326/4/3/035006, 2009.

Döll , P. and Fiedler, K.: Global-scale modeling of groundwater recharge, Hydrol. Earth Syst. Sci., 12, 863-885, 2008, http://www.hydrol-earth-syst-sci.net/12/863/2008/.

Döll, P., Kaspar, F., and Lehner, B.: A global hydrological model for deriving water availability indicators: model tuning and validation, J. Hydrol., 270(1-2), 105-134, 2003.

Döll, P. and Siebert, S.: Global modeling of irrigation water requirements, Water Resour. Res., 38(4), 81-810, 2002.

Dudgeon, D., Arthington, A. H., Gessner, M. O., Kawabata Z.-I., Knowler, D. J., Lévêque, C., Naiman, R. J., Prieur-Richard, A.H., Soto, D., Stiassny, M. L. J., and Sullivan, C. A.: Freshwater biodiversity: importance, threats, status and conservation challenges, Biol. Rev., 81, 163-182, 2006.

Foster, S. and Loucks, D. P. (eds.): Non-renewable groundwater resources: a guidebook on socially-sustainable management for water-policy makers, IHP-VI Series on Groundwater, 10, UNESCO, 103 pp., 2006.

Fuchs, T., Schneider, U., and Rudolf, B.: GPCC Annual Report for Year 2007, GPCC/Deutscher Wetterdienst, http://gpcc.dwd. de, 2007.

Haddeland, I., Skaugen, T., and Lettenmaier, D. P.: Anthropogenic impacts on continental surface water fluxes, Geophys. Res. Lett., 33, L08406, doi:10.1029/2006GL026047,2006.

Hanasaki, N., Kanae, S., and Oki, T.: A reservoir operation scheme for global river routing models, J. Hydrol., 327, 22-41, 2006.

Hunger, M. and Döll, P.: Value of river discharge data for globalscale hydrological modeling, Hydrol. Earth Syst. Sci., 12, 841861,2008 , http://www.hydrol-earth-syst-sci.net/12/841/2008/.

ICOLD (International Commission on Large Dams): World Register of Dams (CD-ROM), Paris, France, 1998.

Kingsford, R. T. and Thomas, R. F.: Destruction of wetlands and waterbird populations by dams and irrigation on the Mur- rumbidgee River in arid Australia, Environ. Manage, 34(3), 383396, 2004.

Janssen, P. H. M. and Heuberger P. S. C.: Calibration of processoriented models, Ecol. Model. 83, 55-66, 1995.

Lehner, B., Reidy Liermann, C., Fekete, B., Vörösmarty, C., Revenga, C., Crouzet, P., Döll, P., Endejan, M., Frenken, K., Magome, J., Robertson, J., Rödel, R., Sindorf, N., and Wisser, D.: Development and Strategies for Application of a Global Reservoir and Dam GRanD) Database, in preparation, 2009.

Lehner, B., Fekete, B., Reidy, C., and Vörösmarty, C.: Global Reservoir and Dam (GRanD) Database - Project Summary, http://www.gwsp.org/current_activities.html, 2008.

Lehner, B. and Döll, P.: Development and validation of a global database of lakes, reservoirs and wetlands, J. Hydrol., 296, 1-22, 2004.

Millennium Ecosystem Assessment: Ecosystems and human wellbeing: wetlands and water synthesis, World Resources Institute, Washington, DC, USA, 2005.

Mitchell, T. D. and Jones, P. D.: An improved method of constructing a database of monthly climate observations and associated high-resolution grids, Int. J. Climatology, 25, 693-712, 2005.

Nilsson, C., Reidy, C. A., Dynesius, M., and Revenga, C.: Fragmentation and flow regulation of the world's large river systems, Science, 308(5720), 405-408, 2005.

Poff, N. L., Olden, J. D., Merritt, D. M., and Pepin, D. M.: Homogenization of regional river dynamics by dams and global biodiversity implications, P. Natl. Acad. Sci. USA, 104(14), 5732-5737, 2007.

Poff, N. L., Allan, D. J., Brain, M. B., Karr, J. R., Prestegaard, K. L., Richter, B. D., Sparks, R. E., and Stromberg, J. C.: The natural flow regime: a paradigm for river conservation and restoration, Bioscience, 47(11), 769-784, 1997.

Poff, N. L. and Ward, J. V.: Implications of stream flow variability and predictability for lotic community structure: a regional analysis of stream flow patterns, Can. J. Fish. Aquat. Sci., 46, 1805-1818, 1989.

Puckridge, J. T., Sheldon, F., Walker, K. F., and Boulton, A. J.: Flow variability and the ecology of large rivers, Mar. Freshwater Res., 49, 55-72, 1998.

Revenga, C., Campbell, I., Abell, R., de Villiers, P., and Bryer, M.: Prospects for monitoring freshwater ecosystems towards the 2010 targets, Phil. Trans. R. Soc. B, 360, 397-413.

Richter, B. D., Baumgartner, J. V., Powell, J., and Braun, D. P.: A method for assessing hydrologic alteration within ecosystems, Conserv. Biol., 10(4), 1163-1174, 1996.

Richter, B. D., Baumgartner, J. V. Wigington, R., and Braun, D. P.: How much water does a river need? Freshwater Biol., 37, 231-249, 1997.

Rost, S., Gerten, D., Bondeau, A., Lucht, W, Rohwer, J., and Schaphoff, S.: Agricultural green and blue water consumption and its influence on the global water system, Water Resour. Res., 44, W09405, doi:10.1029/2007WR006331, 2008.

Siebert, S., Döll, P., Hoogeveen, J., Faures, J.-M., Frenken, K., and Feick, S.: Development and validation of the global map of irrigation areas, Hydrol. Earth Syst. Sci., 9, 535-547, 2005, http://www.hydrol-earth-syst-sci.net/9/535/2005/.

Smakhtin, V., Revenga, C., and Döll, P.: A pilot global assessment of environmental water requirements and scarcity, Water Int., 29(3), 307-317, 2004. 
Vogl, A. L. and Lopes, V. L.: Impact of water resources development on flow regimes in the Brazos River, Environ. Monit. Assess., 157, 331-345, doi:10.1007/s10661-008-0538-5, 2009.

Vörösmarty, C. J., Sharma, K. P., Fekete, B. M., Copeland, A. H., Holden, J., Marble, J., and Lough, J. A.: The storage and aging of continental runoff in large reservoir systems of the world, AMBIO, 26(4), 210-219, 1997.

World Commission of Dams: Dams and Development, Earthscan, 2000 .
Xenopoulos, M. A., Lodge, D. M., Alcamo, J., Märker, M., Schulze, K., and van Vuuren, D. P.: Scenarios of freshwater fish extinctions from climate change and water withdrawal, Glob. Change Biol., 11, 1557-1564, 2005.

Yang, D., Ye, B., and Kane, D.: Streamflow changes over Siberian Yenisey River basin, J. Hydrol., 296, 59-80, 2004. 